\title{
Synthetic studies of the spirocyclic cyclohexene part of versipelostatin, a novel GRP78/Bip molecular chaperone downregulator
}

\author{
Shu Sasaki, Suguru Samejima, Tomoki Uruga, Kai Anzai, Natsumi Nishi, Eriko Kawakita, Ken-ichi Takao \\ and Kin-ichi Tadano \\ The spirocyclic part consisting of an $\alpha$-acylated tetronic acid and a multisubstituted cyclohexene embedded in versipelostatin, a \\ novel GRP78/Bip molecular chaperone downregulator, has been synthesized in enantiomerically pure form. The asymmetric \\ synthesis of the targeted spiro[4.5]-1-oxa-7-decen-2,4-dione derivative was characterized by (1) stereoselective allylation at the \\ $\alpha$-carbon of methylmalonate diester, in which one carboxylic acid was esterified with a D-glucose-derived chiral template, (2) \\ construction of the tetrasubstituted cyclohexenone substructure by high-yielding ring-closing metathesis and (3) stereoselective \\ construction of the spirocyclic tetronic acid part starting from the cyclohexenone obtained as the ring-closing metathesis \\ product.
}

The Journal of Antibiotics (2013) 66, 147-154; doi:10.1038/ja.2012.124; published online 30 January 2013

Keywords: $\alpha$-acyltetronic acid; asymmetric quaternary carbon; ring-closing metathesis; spirocyclic cyclohexene; versipelostatin

\section{INTRODUCTION}

In 2002, Shin-ya et al. ${ }^{1}$ reported the isolation and structural elucidation of a macrocyclic compound of microbial origin designated as versipelostatin (1) (Figure 1). Compound $\mathbf{1}$ was isolated from the culture broth of Streptomyces versipellis 4083-SVS6 as a novel GRP78 molecular chaperone downregulator. The protein GRP78 acts as a molecular chaperone in endoplasmic reticulum (ER) by associating transiently with incipient proteins as they traverse the ER and aiding in their folding and transport. GRP78 is induced under various kind of stresses such as glucose starvation, inhibition of protein glycosylation triggered by tunicamycin, perturbation of ER function and protein movement triggered by brefeldin A and so on. The enhancement of ER stress response causes an increase in gene expression of a number of ER chaperones, thus compounds that directly down- and upregulate grp78 transcription are expected to be promising candidates as cancer chemotherapeutic agents. The structure of 1 was elucidated based on extensive NMR analyses, such as DQF-COSY and HMBC techniques. As a result, the structure of 1 was determined to consist of a novel 17-membered carbocyclic aglycon and a trisaccharide unit. $^{2}$ Later, the relative and absolute stereochemistries of the aglycon in $\mathbf{1}$ were fully determined as shown in Figure 1, including an $\alpha$-acylated tetronic acid that shared a spiro[5.4]-1-oxa-7-decen-2,4-dione structure with a tetrasubstituted cyclohexene. ${ }^{3}$ The cyclohexene part includes an all-carbon asymmetric quaternary carbon as C24.(Numbering of the skeletal carbon in versipelostatin is accordant with that used in reference 1.) The tetronic acid part is connected with a highly functionalized transfused octahydronaphthalenone (C4-C13) through a carbonyl carbon (C3). The whole 17-membered macrocyclic structure of the aglycon is formed by connecting both the spirocyclic cyclohexene and the octahydronaphthalenone parts through a 10-carbon tether (C14C23). The C14-C23 chain, which is considered to be a polyketide array, includes an E-trisubstituted olefin and four stereogenic centers. The biosynthetic studies of $\mathbf{1}$ were also reported by Shin-ya et al., ${ }^{4}$ which were executed by means of feeding experiments using ${ }^{13} \mathrm{C}$ labeled precursors such as $\left[1-{ }^{13} \mathrm{C}\right]$ acetate, $\left[3-{ }^{13} \mathrm{C}\right]$ propionate, $\left[1-{ }^{13} \mathrm{C}\right]$ butyrate and $\left[1,2,3-{ }^{13} \mathrm{C}\right]$ glycerol. Regarding the trisaccharide unit, the early papers from the Shin-ya group reported an incorrect structure for the trisaccharide unit as a $\beta$-D-digitoxosyl- $(1,4)-\alpha$-Dcymarosyl- $(1,4)-\beta$-D-digitoxose. ${ }^{1-4} \quad$ Furthermore, the absolute stereochemistry of the aglycon part was determined based on the structure of the trisaccharide unit. ${ }^{4}$ In 2006, Kunst and Kirschnig ${ }^{5}$ declared the synthesis of the proposed structure of the trisaccharide unit. Recently, Tanaka et al. have reported the synthesis of the trisaccharide unit in versipelostatin and revision of its structure. ${ }^{6}$ Though their synthetic work, the structure of the trisaccharide was revised to be a $\beta$-D-digitoxosyl-(1,4)- $\alpha$-L-oleandrosyl- $(1,4)-\beta$-Ddigitoxose as shown in Figure 1. Since the first report of versipelostatin (1) in 2002, the Shin-ya group has further investigated the secondary metabolites isolated from S. versipellis 4083-SVS56. As a

Department of Applied Chemistry, Keio University, Yokohama, Japan

Correspondence: Professor K Tadano, Department of Applied Chemistry, Keio University, 3-14-1, Hiyoshi, Kohoku-ku, Yokohama, Kanagawa 223-8522, Japan.

E-mail: tadano@applc.keio.ac.jp

This paper is dedicated to Professor Kuniaki Tatsuta with respect and admiration for his achievement of the total syntheses of more than 100 natural products including important antibiotics.

Received 29 November 2012; revised 13 December 2012; accepted 18 December 2012; published online 30 January 2013 
result, they reported the isolation and characterization of a novel analog of 1, designated as versipelostatin F (2) as shown in Figure 1. ${ }^{7}$ Compound $\mathbf{2}$ is an analog regarding the trisaccharide unit. Furthermore, the Shin-ya group reported additional four differently glycosylated derivatives of versipelostatin, designated as versipelostatin B-E. ${ }^{8}$ All of these analogs inhibited the expression of GRP78 induced by 2-deoxyglucose. They also suggested that the structure of the deoxysugar parts such as $\alpha$ - or $\beta$-configured trisaccharides or disaccharides may have an important role in downregulating GRP78 expression. Besides the synthetic studies on the trisaccharide unit, the synthesis of the 17-membered aglycon has been an interest of some groups including ours. Recently, Katsuta et al. ${ }^{9}$ reported their synthetic effort on the enantiospecific construction of the spirocyclic part. They used a cyclic monoterpene $(R)-(+)$-pulegone as a starting material. In their synthetic studies, after introduction of the spirocyclic tetronate, the cyclohexane ring of pulegone was functionalized via a somewhat lengthy route, providing the spirocyclic part of versipelostatin (1) in an unnatural enantiomeric form.

We have been involved for these several years in the total synthesis of versipelostatin (1) in natural form, especially in stereoselective synthesis of the aglycon of $\mathbf{1}$. Our grand design for synthesizing the aglycon $\mathbf{A}$ is shown in Figure 2. The properly protected aglycon $\mathbf{A}$ is divided into three segments $\mathbf{B}, \mathbf{C}$ and $\mathbf{D}$. These segments would be connected sequentially for constructing the 17-membered macrocyclic skeleton, through a cross metathesis between segments $\mathbf{B}$ and $\mathbf{C}$, through a Julia-Kocienski olefination between segments $\mathbf{C}$ and $\mathbf{D}$, and through an aldol-like bond-forming reaction between segments $\mathbf{B}$ and D. We have already developed stereoselective and scalable synthetic routes to segment $\mathbf{C}$, a linear polyketide part $(\mathrm{C} 15-\mathrm{C} 21)^{10}$ and to segment D, a highly functionalized octahydronaphthalene part (C3C14), ${ }^{11}$ both with all the necessary stereogenic centers in correct stereochemistry. In this article, we report our synthetic efforts on efficient and enantioselective access to a compound corresponding to

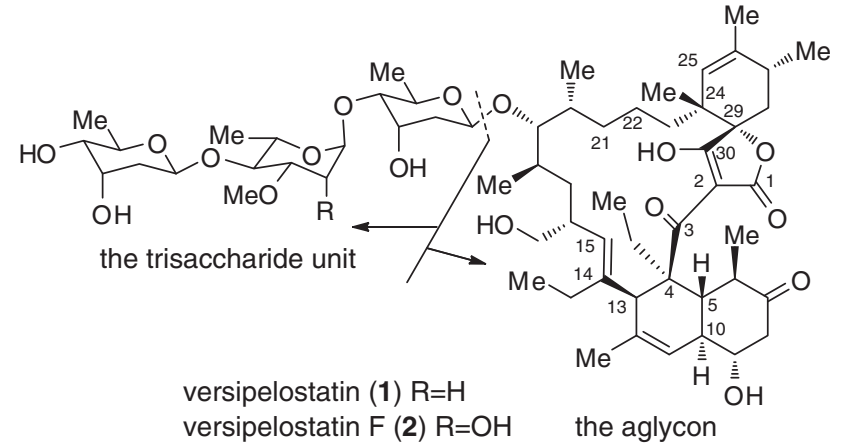

Figure 1 the spirocyclic part (segment B) sharing a tetronic acid and a highly functionalized cyclohexene. Our synthesis of the cyclohexene part of segment B was efficiently achieved though a highly stereoselective introduction of an all-carbon asymmetric quaternary center (C24) by stereoselective $\alpha$-alkylation of a sugar-bound methylmalonate diester, and a ring-closing metathesis for constructing the $(Z)$-trisubstituted olefin (C25-C26).

\section{RESULTS AND DISCUSSION}

During these decades, some notable synthetic approaches toward functionalized tetronic acid and related compounds in the context of natural product synthesis have been published, ${ }^{12-14}$ and well reviewed. ${ }^{15}$ We selected spirocyclic compound 3 as a synthetic precursor of segment B. Our retrosynthetic approach to $\mathbf{3}$ is summarized in Scheme $1 .{ }^{16}$ The protected tetronic acid part in 3 would be accessible through the 1,4-addition of an oxygen nucleophile such as a methoxy anion to methylpropiolate 4, followed by transesterification (lactonization). The propiolate $\mathbf{4}$ could be obtained by a stereoselective addition of the acetylide derived from methyl propiolate to cyclohexenone 5. The 2,2,4,5tetrasubstituted 3-cyclohexen-1-one 5 (C24-C29 in 1) would be obtained by the ring-closing metathesis of a 3,3,6,7-tetraalkylated 1,7-octadien-4-one $\mathbf{6}$, which in turn would be obtained by the Grignard coupling between aldehyde 7 and an organometallic species 8 followed by oxidation. For enantioselective synthesis of aldehyde 7, we envisioned the sugar-template-based introduction of the all-carbon asymmetric quaternary center in 7 , which has been extensively developed in our group during the later half of 2000s. On the other hand, the Grignard reagent $\mathbf{8}$ would be readily accessible from commercially available methyl $(R)-(-)$-3-hydroxyisobutyrate (9) using a slight modification of known procedure. ${ }^{17}$ In the retrosynthetic plan, 7 would be obtainable from a 4-O-acylated D-glucopyranoside $\mathbf{1 0}$ by removal of the sugar moiety. In relation to this sugar derivative $\mathbf{1 0}$, we have developed a stereoselective quaternarization at the $\alpha$-carbon of acetoacetates attached at C4 of methyl 6-deoxy-2,3-di-O-(tert-butyl)dimethylsilyl- $\alpha$-D-glucopyranoside (12) or at $\mathrm{C} 2$ of methyl 6-deoxy-3,4-di-O-(tertbutyl)dimethylsilyl- $\alpha$-D-glucopyranoside, both of which produced the corresponding $\alpha$-methyl- $\alpha$-allylacetoacetate highly stereoselectively. ${ }^{18-20}$ The sugar template $\mathbf{1 2}$, served as an efficient chiral auxiliary for asymmetric synthesis, is readily prepared in a multi-10gram scale from methyl D-glucopyranoside, ${ }^{21}$ and its utility has been well recognized through a variety of diastereoselective carbon-carbon bond-forming reactions. ${ }^{22-24}$

With this synthetic design in mind, we embarked on the synthesis of 3. In Scheme 2, the stereoselective construction of an all-carbon asymmetric quaternary center corresponding to C24 in 3, which was

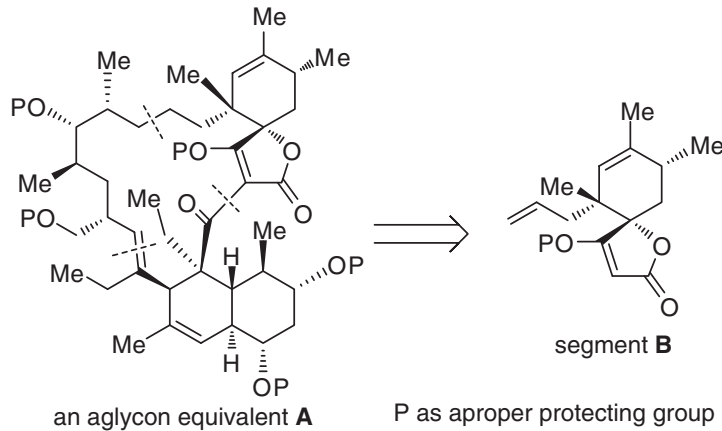

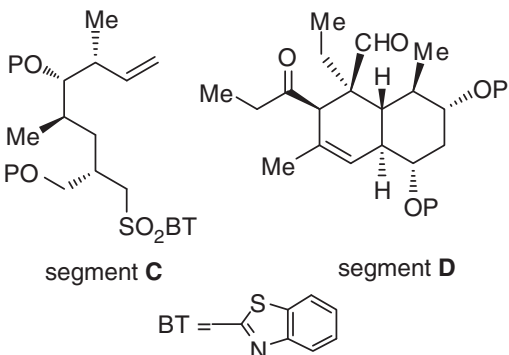

Figure 2 
achieved using the sugar-template 12, is summarized. Diethyl methylmalonate (13) was quantitatively hydrolyzed with $\mathrm{KOH}$ in EtOH provided 2-(ethoxycarbonyl)propionic acid (14). ${ }^{25}$ The attachment of monocarboxylic acid $\mathbf{1 4}$ to the chiral template $\mathbf{1 2}$ was achieved using dicyclohexylcarbodiimide as a dehydrating reagent, producing the 4-O-(2-ethoxycarbonyl)propionyl derivative 15 of 12, as an inseparable 1:1 diastereomeric mixture, quantitatively. For the quaternization at the $\alpha$-carbon of the resulting diester 15 , allyl bromide was used as an electrophile after deprotonation with $\mathrm{NaOEt}$ analogously to our previous reports. ${ }^{18,19}$ As expected, the attack of allyl bromide to thus formed enolate proceeded with complete $\pi$-facial selectivity to produce the allylation product $\mathbf{1 1}$ as a single diastereomer in almost quantitative yield. The stereochemistry at the newly formed stereogenic center in $\mathbf{1 1}$ as shown was determined unambiguously by chemical transformation of $\mathbf{1 1}$ to an authentic specimen of our previously reported compound. (Compound 11 was converted into methyl 2,3-di-O-(tert-butyldimethylsilyl)-6-deoxy4-O-((2R)-2-allyl-2-methyl-3-oxo-butanoyl)- $\alpha$-D-glucopyranoside, compound $\mathbf{9}^{18}$, as follows: (1) Selective reduction of the ethoxycarbonyl moiety with diisobutyl aluminium hydride (Dibal-H) in toluene at $-78{ }^{\circ} \mathrm{C}(80 \%)$; (2) tetrapropylammonium perruthenate (TPAP) oxidation of the resulting primary alcohol in the presence of $\mathrm{N}$-methylmorpholine $\mathrm{N}$-oxide (NMO) in $\mathrm{CH}_{2} \mathrm{Cl}_{2}$ and molecular sieves (MS) $4 \AA$ (93\%); (3) $\mathrm{MeMgCl}$ addition to the resulting aldehyde in $\mathrm{Et}_{2} \mathrm{O}$ at $-78{ }^{\circ} \mathrm{C}(60 \%)$; (4) Dess-Martin oxidation of the resulting diastereomeric mixture of the addition products in the presence of $\mathrm{NaHCO}_{3}$ in $\mathrm{CH}_{2} \mathrm{Cl}_{2}$ (91\%). Thus, obtained product was identical with the authentic sample in all spectral means.)

As shown in Scheme 3, ozonolysis of the vinyl group in $\mathbf{1 1}$ followed by reductive workup with $\mathrm{Ph}_{3} \mathrm{P}$ produced the formylmethyl derivative 16 in $90 \%$ yield. The aldehyde group in $\mathbf{1 6}$ was protected as a 1,3-dioxolan-2-yl form by treatment with ethylene glycol in the

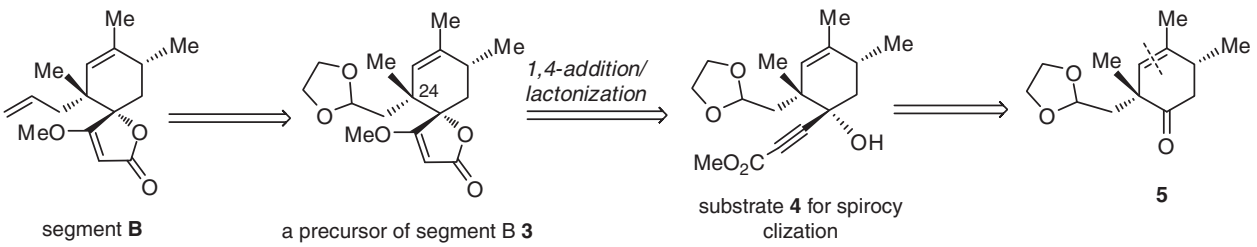
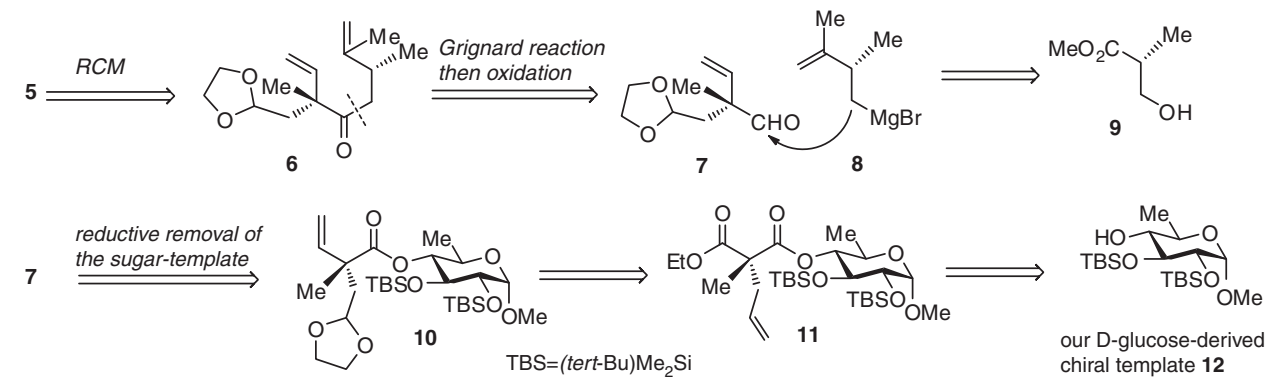

Scheme 1

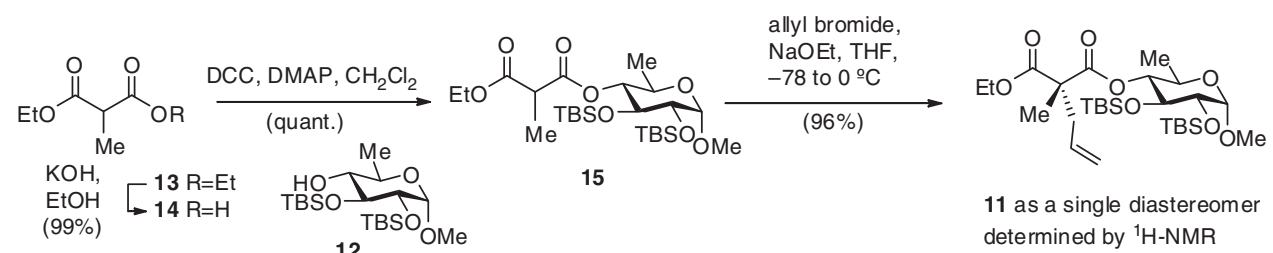

Scheme 2

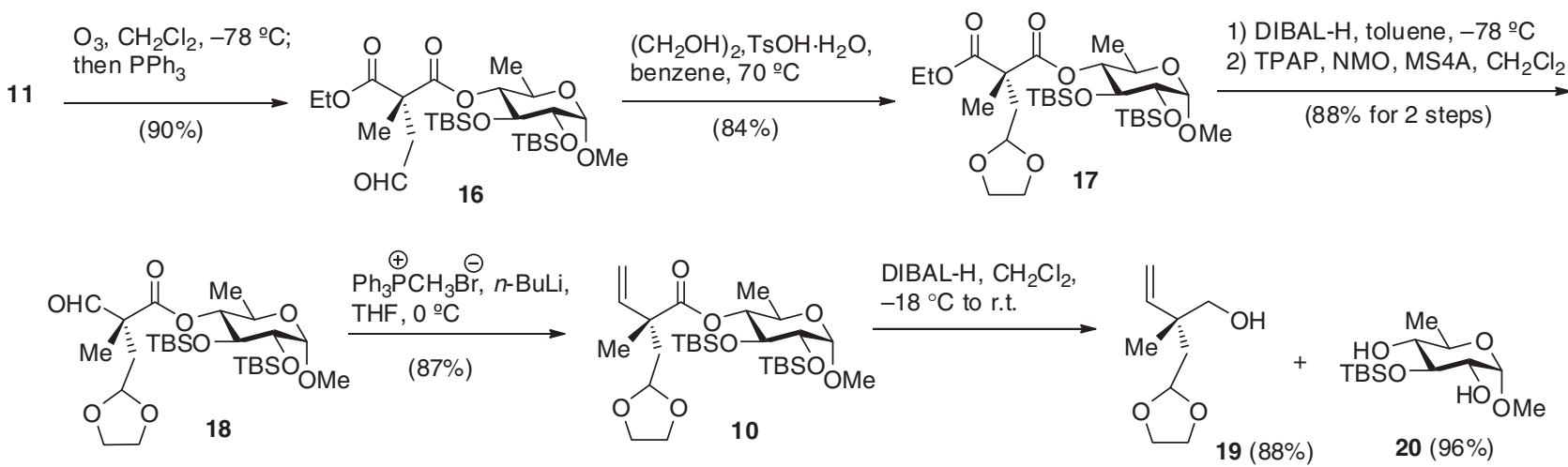


presence of $\mathrm{TsOH} \cdot \mathrm{H}_{2} \mathrm{O}$ in hot benzene. The thus obtained acetal 17 was reduced with Dibal-H and the resulting mixture of aldehyde 18 and the primary alcohol was oxidized without purification with TPAP in the presence of NMO to produce 18 in $88 \%$ yield for two steps. Wittig olefination of aldehyde 18 with methyltriphenylphosphonium bromide in the presence of $n$-BuLi at $0{ }^{\circ} \mathrm{C}$ provided the vinyl derivative 10. Removal of the sugar-template from 10 was best achieved by Dibal-H reduction at $-18{ }^{\circ} \mathrm{C}$, producing a neopentyl alcohol 19 in a good yield of $88 \%$. The 3 -O-silylated D-glucopyranoside 20 was also obtained in $96 \%$ yield. Under these reduction conditions, the tert-butyldimethylsilyl group at $\mathrm{C} 2$ in $\mathbf{1 2}$ was selectively removed. (Treatment of $\mathbf{2 0}$ with tertbuthyldimethylsilyl chloride (1.5 eq) in the presence of imidazole (3.0 eq) in DMF at room temperature ( $\mathrm{rt}$ ) for $15 \mathrm{~h}$ provided the sugartemplate 12 selectively in $72 \%$ yield and 20 was recovered in $28 \%$ yield.)

For preparing the Grignard reagent 8 in Scheme 1, the corresponding alkyl bromide 22 was prepared as shown in Scheme 4. According to the reported procedure, ${ }^{17}(R)-(-)$-Roche ester (9) was converted into tosylate 21 in an overall yield of $55 \%$. Replacement of the tosyloxy group in 21 by a bromide anion provided the homoallyl bromide 22
As shown in Scheme 5, the homoallylic alcohol 19 was converted into aldehyde 7 by Dess-Martin oxidation. The Grignard addition of the homoallylmagnesium bromide prepared from 22 to 7 produced the adduct 23 as an inseparable diastereomeric mixture (1:1) in 59\% yield. The reduction product 19 was obtained in $36 \%$ yield as a result of hydride transfer from the Grignard reagent to the aldehyde 7. Despite searching more efficient Grignard reaction conditions, we could not find the reliable conditions for avoiding this reduction reaction. The diastereomeric mixture $\mathbf{2 3}$ was then oxidized smoothly to ketone 6 by Dess-Martin oxidation. The ring-closing metathesis of dienone 6 proceeded smoothly using $5 \mathrm{~mol} \%$ of the Grubbs second-generation catalyst $24^{26}$ in toluene at $80^{\circ} \mathrm{C}$ for $19 \mathrm{~h}$ to produce a tetrasubstituted 3-cyclohexen-1-one $\mathbf{5}$ in $90 \%$ yield. (The use of the Grubbs first-generation catalyst in toluene at $80^{\circ} \mathrm{C}$ did not promote the ring-closing metathesis reaction, and 6 was recovered quantitatively.)

In Scheme 6, our approach to the spirocyclic segment B precursor 3 is depicted. According to some precedent reports, ${ }^{12,27}$ we explored first the reaction between cyclohexenone $\mathbf{5}$ and methyl trans-3methoxyacrylate for a one-step access to $\mathbf{3}$ using lithium diisopropylamide as the base at $-78^{\circ} \mathrm{C}$ in tetrahydrofuran (THF) in the absence or presence of $\mathrm{CeCl}_{3}$. Both cases resulted in complete

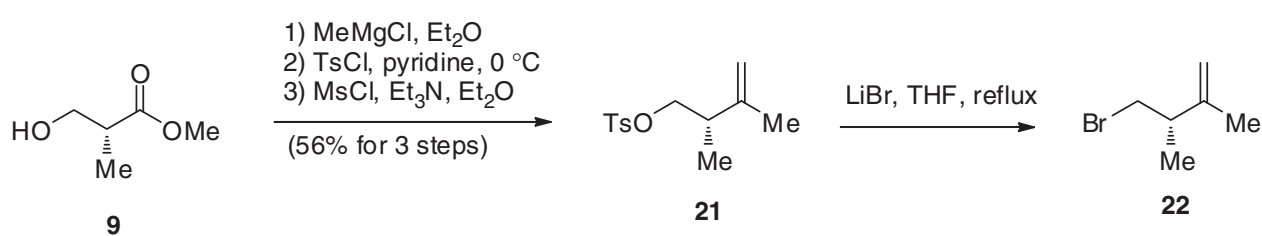

Scheme 4

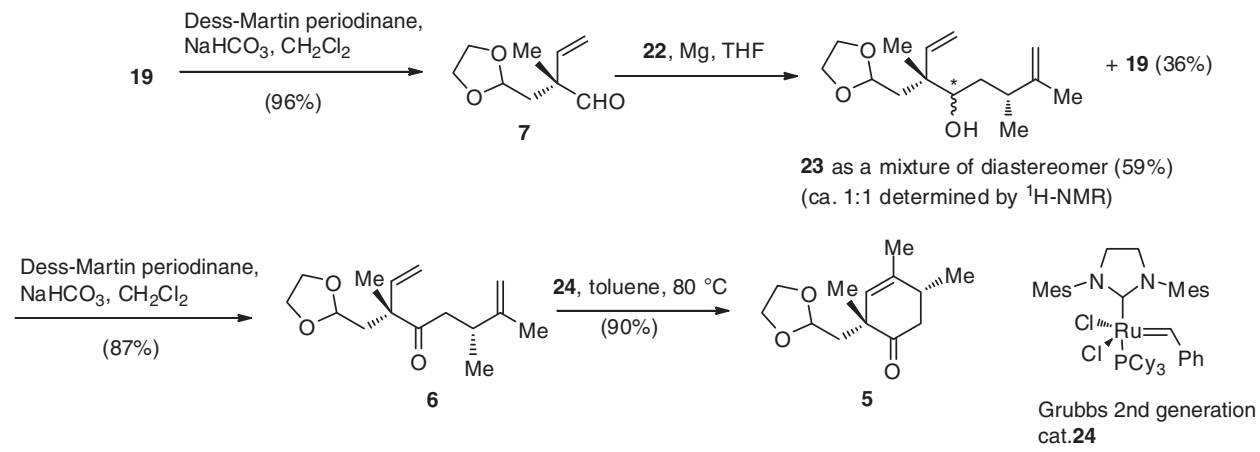

Scheme 5

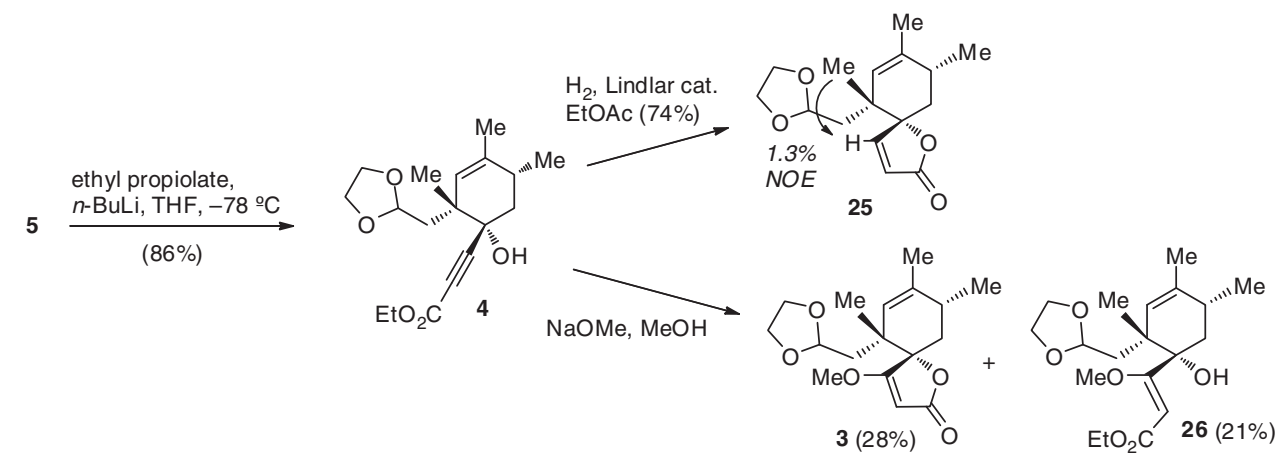


recovery of $\mathbf{5}$. Next, the addition of the lithium acetylide prepared from ethyl propiolate with $n$-BuLi in THF at $-78^{\circ} \mathrm{C}$ to 5 was examined. Fortunately, the addition product 4 was obtained stereoselectively in $86 \%$ yield. The stereochemistry at the newly introduced chiral center in $\mathbf{4}$ was ascertained by the NOE experiment of 25 , obtained by hemihydrogenation of acetylenic ester 4 using Lindler catalyst followed by spontaneous lactonization occurred between the resulting ethyl cis-propenoate and the tertiary hydroxyl group. Consequently, the attack of the acetylide occurred exclusively from the less hindered $R e$-face of the carbonyl in 5 . The expected 1,4-addition of a methoxide ion from $\mathrm{NaOMe}$ to the $\beta$ carbon of the propiolate 4 followed by lactonization did not occur at room temperature. Only the corresponding methyl propiolate was obtained as a result of transesterification. After some experimentation, we found eventually that treatment of $\mathbf{4}$ with $\mathrm{NaOMe}$ in $\mathrm{MeOH}$ for prolonged heating at $60^{\circ} \mathrm{C}$ provided the desired spirocyclic tetranote 3 in a yield of $28 \%$. Another isolable product was the $\beta$-methoxy- $\alpha, \beta$ unsaturated ester 26 , the 1,4-addition product with Z-configuration, which was obtained in $21 \%$ yield.

In summary, we have developed the stereoselective synthesis of $\mathbf{3}$ as a synthetic equivalent to the spirocyclic part in versipelostatin. Our approach to 3 is featured by (1) exclusive construction of the desired all-carbon quaternary center (C24) using our D-glucose-derived chiral-template approach; (2) convenient synthesis of tetrasubstituted cyclohexenone by a ring-closing olefin-metathesis approach and (3) spirocyclic formation via the 1,4-addion of a methoxide ion to the propiolate 4 . We are seeking a more efficient access to $\mathbf{3}$ using $\mathbf{5}$ as an advanced intermediate.

\section{EXPERIMENTAL PROCEDURE}

\section{General}

Specific rotations were measured in a $100-\mathrm{mm}$ cell. ${ }^{1} \mathrm{H}$ NMR spectra were recorded at 300 or $500 \mathrm{MHz}$ with tetramethylsilane as an internal standard. ${ }^{13} \mathrm{C}$ NMR spectra were recorded at $125 \mathrm{MHz}$. High-resolution mass spectra (HRMS) were measured in electron ionization (EI) mode $(70 \mathrm{eV})$. Thin-layer chromatography (TLC) was performed on Merck Kieselgel $60 \mathrm{~F}_{254}$ plates. The crude reaction mixtures and extracted materials were purified by column chromatography on Silica gel 60 (Merck, Darmstadt, Germany). Unless otherwise noted, the reactions were carried out at room temperature. Combined organic extracts were dried over anhydrous $\mathrm{Na}_{2} \mathrm{SO}_{4}$. The solvents were removed from the reaction mixture and the combined organic extracts by concentration under reduced pressure using an evaporator with bath at $35-45^{\circ} \mathrm{C}$

2-(Ethoxycarbonyl)propanoic acid (14). To a cooled $\left(0^{\circ} \mathrm{C}\right)$, stirred solution of diethyl methylmalonate $(13)(2.00 \mathrm{ml}, 11.7 \mathrm{mmol})$ in $\mathrm{EtOH}(40 \mathrm{ml}), \mathrm{KOH}$ (789 mg, $14.1 \mathrm{mmol}$ ) was added. After being stirred at rt for 2 hours, the mixture was diluted with $\mathrm{H}_{2} \mathrm{O}(60 \mathrm{ml})$ and washed with hexane/THF (2:3, $100 \mathrm{ml}) .1 \mathrm{M}$ aqueous $\mathrm{HCl}(30 \mathrm{ml})$ was added to the aqueous layer. The mixture was extracted with $\mathrm{CH}_{2} \mathrm{Cl}_{2}(20 \mathrm{ml} \times 3)$. The combined extracts were dried and concentrated in vacuo to provide $1.70 \mathrm{~g}(100 \%)$ of $\mathbf{1 4}$ as a colorless oil, which was used in the next step without further purification: TLC $\mathrm{R}_{\mathrm{f}} 0.50$ (EtOAc/ hexane, 3:1); ${ }^{1} \mathrm{H}-\mathrm{NMR}\left(300 \mathrm{MHz}, \mathrm{CDCl}_{3}\right) \delta 1.28(\mathrm{t}, 3 \mathrm{H}, \mathrm{J}=7.1 \mathrm{~Hz}), 1.45(\mathrm{~d}$, $3 \mathrm{H}, \mathrm{J}=7.4 \mathrm{~Hz}), 3.47(\mathrm{q}, 1 \mathrm{H}, \mathrm{J}=7.4 \mathrm{~Hz}), 4.22(\mathrm{q}, 2 \mathrm{H}, \mathrm{J}=7.1 \mathrm{~Hz}) ;{ }^{13} \mathrm{C}-\mathrm{NMR}$ $\left(125 \mathrm{MHz}, \mathrm{CDCl}_{3}\right) \delta 13.5,14.0,45.9,61.7,169.9,175.8$.

Methyl 2,3-di-O-(tert-butyldimethylsilyl)-6-deoxy-4-O-(2-(ethoxycarbonyl)propanoyl)- $\alpha$-D-glucopyranoside (15). To a stirred solution of $\mathbf{1 2}(1.90 \mathrm{~g}$, $4.67 \mathrm{mmol})$ in $\mathrm{CH}_{2} \mathrm{Cl}_{2}(38 \mathrm{ml})$, DMAP $(57.1 \mathrm{mg}, 0.467 \mathrm{mmol})$, a solution of $14(818 \mathrm{mg}, 5.60 \mathrm{mmol})$ in $\mathrm{CH}_{2} \mathrm{Cl}_{2}(10 \mathrm{ml})$ and dicyclohexylcarbodiimide $(1.16 \mathrm{~g}, 5.60 \mathrm{mmol})$ were added. The mixture was stirred at $\mathrm{rt}$ for $15 \mathrm{~h}$, and a solution of $14(273 \mathrm{mg}, 1.87 \mathrm{mmol})$ in $\mathrm{CH}_{2} \mathrm{Cl}_{2}(2.4 \mathrm{ml})$ and dicyclohexylcarbodiimide $(387 \mathrm{mg}, 1.87 \mathrm{mmol}$ ) were added. After being stirred at $\mathrm{rt}$ for $3 \mathrm{~h}$, the mixture was diluted with $\mathrm{H}_{2} \mathrm{O}(80 \mathrm{ml})$ and extracted with $\mathrm{CH}_{2} \mathrm{Cl}_{2}$ $(20 \mathrm{ml} \times 3)$. The combined extracts were dried and concentrated in vacuo.
The residue was purified by column chromatography on silica gel (EtOAc/ hexane, 1:40) to provide $2.44 \mathrm{~g}$ (98\% from 12) of $\mathbf{1 5}$ ( $c a$. 1:1 diastereomeric mixture) as a colorless oil: TLC $\mathrm{R}_{\mathrm{f}} 0.60$ (EtOAc/hexane, 1:5); IR (neat) 2931, $1757 \mathrm{~cm}^{-1}$; ${ }^{1} \mathrm{H}-\mathrm{NMR}\left(300 \mathrm{MHz}, \mathrm{CDCl}_{3}\right) \delta 0.05(\mathrm{~s}, 3 \mathrm{H}), 0.07$ (s, 3H), $0.10(\mathrm{~s}$, $6 \mathrm{H}), 0.83(\mathrm{~s}, 9 \mathrm{H} \times 1 / 2), 0.86(\mathrm{~s}, 9 \mathrm{H} \times 1 / 2), 0.92(\mathrm{~s}, 9 \mathrm{H}), 1.13(\mathrm{~d}, 3 \mathrm{H} \times 1 / 2$, $J=6.6 \mathrm{~Hz}), 1.18(\mathrm{~d}, 3 \mathrm{H} \times 1 / 2, J=6.6 \mathrm{~Hz}), 1.27(\mathrm{t}, 3 \mathrm{H} \times 1 / 2, J=7.2 \mathrm{~Hz}), 1.28$ $(\mathrm{t}, 3 \mathrm{H} \times 1 / 2, J=7.2 \mathrm{~Hz}), 1.42(\mathrm{~d}, 3 \mathrm{H} \times 1 / 2, J=7.2 \mathrm{~Hz}), 1.46(\mathrm{~d}, 3 \mathrm{H} \times 1 / 2$, $J=7.2 \mathrm{~Hz}), 3.36(\mathrm{~s}, 3 \mathrm{H} \times 1 / 2), 3.37(\mathrm{~s}, 3 \mathrm{H} \times 1 / 2), 3.42-3.52(\mathrm{~m}, 1 \mathrm{H}), 3.66(\mathrm{dd}$, $1 \mathrm{H}, J=3.5,8.9 \mathrm{~Hz}), 3.91(\mathrm{t}, 1 \mathrm{H} \times 1 / 2, J=8.9 \mathrm{~Hz}), 3.92(\mathrm{t}, 1 \mathrm{H} \times 1 / 2, J=8.9$ $\mathrm{Hz}), 4.19(\mathrm{q}, 2 \mathrm{H}, J=7.2 \mathrm{~Hz}), 4.61(\mathrm{~d}, 1 \mathrm{H}, J=3.5 \mathrm{~Hz}), 4.69(\mathrm{dd}, 1 \mathrm{H} \times 1 / 2$, $J=6.0,8.9 \mathrm{~Hz}), 4.72(\mathrm{dd}, 1 \mathrm{H} \times 1 / 2, J=6.0,8.9 \mathrm{~Hz}) ;{ }^{13} \mathrm{C}-\mathrm{NMR}(125 \mathrm{MHz}$, $\left.\mathrm{CDCl}_{3}\right) \delta-4.5(3 / 2 \mathrm{C}),-4.4(1 / 2 \mathrm{C}),-3.4,-3.0(1 / 2 \mathrm{C}),-2.9(1 / 2 \mathrm{C}), 13.6$ (1/2C), 14.0 (1/2C), 14.0 (1/2C), 14.1 (1/2C), $17.4(1 / 2 \mathrm{C}), 17.6(1 / 2 \mathrm{C}), 17.8(1 /$ 2C), 17.8 (1/2C), 18.4, 25.8 (3/2C), 25.9 (3/2C), 26.1 (3C), 46.3 (1/2C), 46.3 (1/2C), 55.0 (1/2C), 55.0 (1/2C), 61.3 (1/2C), 61.5 (1/2C), 65.3 (1/2C), 65.5 (1/2C), $71.6(1 / 2 \mathrm{C}), 71.7$ (1/2C), 74.4, 77.6 (1/2C), 77.6 (1/2C), 100.0, 169.0 (1/2C), $169.6(1 / 2 \mathrm{C}), 169.7(1 / 2 \mathrm{C}), 170.2$ (1/2C); HRMS (EI) calculated for $\mathrm{C}_{21} \mathrm{H}_{41} \mathrm{O}_{8} \mathrm{Si}_{2}\left(\mathrm{M}^{+}-t-\mathrm{C}_{4} \mathrm{H}_{9}\right) \mathrm{m} / z$ 477.2340, found 477.2349.

Methyl 2,3-di-O-(tert-butyldimethylsilyl)-6-deoxy-4-O-((2R)-2-ethoxycarbonyl-2-methylpent-4-enoyl)- $\alpha$-D-glucopyranoside (11). The following reaction was carried out under Ar. To a cooled $\left(-78^{\circ} \mathrm{C}\right)$ stirred solution of 15 $(2.44 \mathrm{~g}, 4.56 \mathrm{mmol})$ in THF $(49 \mathrm{ml}), \mathrm{NaOEt}(1.0 \mathrm{M}$ in EtOH, $4.79 \mathrm{ml}$, $4.79 \mathrm{mmol}$ ) was added. The mixture was stirred at $-78^{\circ} \mathrm{C}$ for $15 \mathrm{~min}$, and allyl bromide $(0.711 \mathrm{ml}, 8.22 \mathrm{mmol})$ was added. After being stirred at $-78^{\circ} \mathrm{C}$ for $30 \mathrm{~min}$, the mixture was warmed to $0^{\circ} \mathrm{C}$ and stirred for $17 \mathrm{~h}$. The mixture was quenched with saturated aqueous $\mathrm{NH}_{4} \mathrm{Cl}(30 \mathrm{ml})$, diluted with EtOAc $(50 \mathrm{ml})$ and washed with saturated aqueous $\mathrm{NH}_{4} \mathrm{Cl}(50 \mathrm{ml} \times 3)$. The organic layer was dried and concentrated in vacuo. The residue was purified by column chromatography on silica gel (EtOAc/hexane, 1:50) to provide $2.44 \mathrm{~g}(96 \%)$ of 11 as a colorless oil: TLC $\mathrm{R}_{\mathrm{f}} 0.68$ (EtOAc/hexane, 1:5); $[\alpha]_{\mathrm{D}}^{27}+48.2(c 0.880$, $\mathrm{CHCl}_{3}$ ); IR (neat) $2956,1735 \mathrm{~cm}^{-1} ;{ }^{1} \mathrm{H}-\mathrm{NMR}\left(300 \mathrm{MHz}, \mathrm{CDCl}_{3}\right) \delta 0.08(\mathrm{~s}$, $12 \mathrm{H}), 0.85$ (s, 9H), $0.93(\mathrm{~s}, 9 \mathrm{H}), 1.17(\mathrm{~d}, 3 \mathrm{H}, J=6.2 \mathrm{~Hz}), 1.26(\mathrm{t}, 3 \mathrm{H}, J=7.2$ $\mathrm{Hz}), 1.43(\mathrm{~s}, 3 \mathrm{H}), 2.47(\mathrm{dd}, 1 \mathrm{H}, J=7.8,13.7 \mathrm{~Hz}), 2.84(\mathrm{dd}, 1 \mathrm{H}, J=6.8$, $13.7 \mathrm{~Hz}), 3.37$ (s, $3 \mathrm{H}), 3.69(\mathrm{dd}, 1 \mathrm{H}, J=3.4,8.1 \mathrm{~Hz}), 3.75(\mathrm{qd}, 1 \mathrm{H}, J=6.2$, $9.7 \mathrm{~Hz}), 3.92(\mathrm{t}, 1 \mathrm{H}, J=8.1 \mathrm{~Hz}), 4.17(\mathrm{q}, 2 \mathrm{H}, J=7.2 \mathrm{~Hz}), 4.62(\mathrm{~d}, 1 \mathrm{H}, J=3.4$ $\mathrm{Hz}), 4.75(\mathrm{dd}, 1 \mathrm{H}, J=8.1,9.7 \mathrm{~Hz}), 5.11(\mathrm{~d}, 1 \mathrm{H}, \mathrm{J}=11.3 \mathrm{~Hz}), 5.12(\mathrm{~d}, 1 \mathrm{H}$, $J=15.6 \mathrm{~Hz}), 5.62-5.76(\mathrm{~m}, 1 \mathrm{H}) ;{ }^{13} \mathrm{C}-\mathrm{NMR}\left(125 \mathrm{MHz}, \mathrm{CDCl}_{3}\right) \delta-4.3,-4.3$, $-3.3,-2.8,14.0,17.8$ (2C), 18.5, 20.3, 26.0 (3C), 26.2 (3C), 40.1, 54.0, 55.0, $61.4,65.6,71.9,74.3,78.5,99.6,119.3,132.6,171.1,171.7$; HRMS (EI) calculated for $\mathrm{C}_{24} \mathrm{H}_{45} \mathrm{O}_{8} \mathrm{Si}_{2}\left(\mathrm{M}^{+}-t-\mathrm{C}_{4} \mathrm{H}_{9}\right) m / z$ 517.2653, found 517.2631.

Methyl 2,3-di-O-(tert-butyldimethylsilyl)-6-deoxy-4-O-((2R)-2-ethoxycarbonyl-2-formylmethylpropanoyl)- $\alpha$-D-glucopyranoside (16). To a cooled $\left(-78{ }^{\circ} \mathrm{C}\right)$ stirred solution of $11(1.48 \mathrm{~g}, 2.60 \mathrm{mmol})$ in $\mathrm{CH}_{2} \mathrm{Cl}_{2}(30 \mathrm{ml}), \mathrm{O}_{3}$ was bubbled at $-78^{\circ} \mathrm{C}$ for $10 \mathrm{~min}$ and $\mathrm{Ph}_{3} \mathrm{P}(810 \mathrm{mg}, 3.09 \mathrm{mmol})$ was added. After being stirred at $0{ }^{\circ} \mathrm{C}$ for $30 \mathrm{~min}$, the mixture was warmed to rt, stirred for $1 \mathrm{~h}$ and concentrated in vacuo. The residue was purified by column chromatography on silica gel (EtOAc/hexane, 1:40) to provide $1.33 \mathrm{~g}(90 \%)$ of $\mathbf{1 6}$ as a colorless oil: TLC $\mathrm{R}_{\mathrm{f}} 0.50$ (EtOAc/hexane, 1:5); $[\alpha]_{\mathrm{D}}^{31}+55.2$ ( $c 1.03, \mathrm{CHCl}_{3}$ ); IR (neat) 2932, $1730 \mathrm{~cm}^{-1}$; ${ }^{1} \mathrm{H}-\mathrm{NMR}\left(300 \mathrm{MHz}, \mathrm{CDCl}_{3}\right) \delta 0.07(\mathrm{~s}, 12 \mathrm{H}), 0.85(\mathrm{~s}, 9 \mathrm{H}), 0.92(\mathrm{~s}$, $9 \mathrm{H}), 1.15(\mathrm{~d}, 3 \mathrm{H}, J=6.2 \mathrm{~Hz}), 1.26(\mathrm{t}, 3 \mathrm{H}, J=7.1 \mathrm{~Hz}), 1.59(\mathrm{~s}, 3 \mathrm{H}), 2.84(\mathrm{dd}$, $1 \mathrm{H}, J=1.2,17.5 \mathrm{~Hz}), 3.20(\mathrm{dd}, 1 \mathrm{H}, J=1.2,17.5 \mathrm{~Hz}), 3.37(\mathrm{~s}, 3 \mathrm{H}), 3.68(\mathrm{dd}$, $1 \mathrm{H}, J=3.4,8.0 \mathrm{~Hz}), 3.73(\mathrm{qd}, 1 \mathrm{H}, J=6.2,9.8 \mathrm{~Hz}), 3.90(\mathrm{t}, 1 \mathrm{H}, J=8.0 \mathrm{~Hz}), 4.21$ $(\mathrm{q}, 2 \mathrm{H}, J=7.1 \mathrm{~Hz}), 4.61(\mathrm{~d}, 1 \mathrm{H}, J=3.4 \mathrm{~Hz}), 4.74(\mathrm{dd}, 1 \mathrm{H}, J=8.0,9.8 \mathrm{~Hz}), 9.73$ $(\mathrm{t}, 1 \mathrm{H}, J=1.2 \mathrm{~Hz}) ;{ }^{13} \mathrm{C}-\mathrm{NMR}\left(125 \mathrm{MHz}, \mathrm{CDCl}_{3}\right) \delta-4.2(2 \mathrm{C}),-3.3,-2.9$, 13.9, 17.7, 17.8, 18.5, 21.4, 25.9 (3C), 26.2 (3C), 48.8, 51.4, 55.0, 62.0, 65.3, $71.9,74.3,79.2,99.5,170.3,170.4,198.2$; HRMS (EI) calculated for $\mathrm{C}_{26} \mathrm{H}_{49} \mathrm{O}_{8} \mathrm{Si}_{2}\left(\mathrm{M}^{+}-\mathrm{OMe}\right) \mathrm{m} / \mathrm{z} 545.2965$, found 545.2966.

Methyl 2,3-di-O-(tert-butyldimethylsilyl)-6-deoxy-4-O-((2R)-2-(1,3-dioxolan2-yl)methyl-2-(ethoxycarbonyl)propanoyl)- $\alpha$-D-glucopyranoside (17). To a stirred solution of $16(1.32 \mathrm{~g}, 2.30 \mathrm{mmol})$ in benzene $(26 \mathrm{ml}),\left(\mathrm{CH}_{2} \mathrm{OH}\right)_{2}(0.191 \mathrm{ml}$, $3.40 \mathrm{mmol})$ and $\mathrm{TsOH} \cdot \mathrm{H}_{2} \mathrm{O}(131 \mathrm{mg}, 0.69 \mathrm{mmol})$ were added. After being stirred at $70^{\circ} \mathrm{C}$ for $3 \mathrm{~h}$, the mixture was quenched with saturated aqueous $\mathrm{NaHCO}_{3}(30 \mathrm{ml})$ at $0{ }^{\circ} \mathrm{C}$ and extracted with $\mathrm{CH}_{2} \mathrm{Cl}_{2}(20 \mathrm{ml} \times 3)$. The combined extracts were dried and concentrated in vacuo. The residue was purified by column chromatography on silica gel (EtOAc/hexane, 1:20) to provide $1.20 \mathrm{~g}(84 \%)$ of 17 as a colorless oil: TLC $\mathrm{R}_{\mathrm{f}} 0.38$ (EtOAc/hexane, 1:5); $[\alpha]_{\mathrm{D}}^{28}+45.6\left(\right.$ c $\left.1.03, \mathrm{CHCl}_{3}\right)$; IR (neat) $2932,1732 \mathrm{~cm}^{-1} ;{ }^{1} \mathrm{H}-\mathrm{NMR}(300 \mathrm{MHz}$, 
$\left.\mathrm{CDCl}_{3}\right) \delta 0.08(\mathrm{~s}, 12 \mathrm{H}), 0.84(\mathrm{~s}, 9 \mathrm{H}), 0.92(\mathrm{~s}, 9 \mathrm{H}), 1.17(\mathrm{~d}, 3 \mathrm{H}, J=6.3 \mathrm{~Hz})$ $1.25(\mathrm{t}, 3 \mathrm{H}, J=7.1 \mathrm{~Hz}), 1.56(\mathrm{~s}, 3 \mathrm{H}), 2.17(\mathrm{dd}, 1 \mathrm{H}, J=5.0,14.4 \mathrm{~Hz}), 2.48$ (dd, $1 \mathrm{H}, J=5.0,14.4 \mathrm{~Hz}), 3.37(\mathrm{~s}, 3 \mathrm{H}), 3.68(\mathrm{dd}, 1 \mathrm{H}, J=3.4,8.2 \mathrm{~Hz}), 3.76-3.85(\mathrm{~m}$, $3 \mathrm{H}), 3.87-3.98(\mathrm{~m}, 2 \mathrm{H}), 3.92(\mathrm{t}, 1 \mathrm{H}, J=8.2 \mathrm{~Hz}), 4.18(\mathrm{q}, 2 \mathrm{H}, J=7.1 \mathrm{~Hz}), 4.61$ $(\mathrm{d}, 1 \mathrm{H}, J=3.4 \mathrm{~Hz}), 4.73(\mathrm{dd}, 1 \mathrm{H}, J=8.2,9.7 \mathrm{~Hz}), 4.94(\mathrm{t}, 1 \mathrm{H}, J=5.0 \mathrm{~Hz}) ;{ }^{13} \mathrm{C}-$ $\operatorname{NMR}\left(125 \mathrm{MHz}, \mathrm{CDCl}_{3}\right) \delta-4.3,-4.2,-3.3,-2.9,13.9,17.8(2 \mathrm{C}), 18.4$, 20.6, 26.0 (3C), 26.2 (3C), 39.1, 52.3, 54.9, 61.5, 64.5, 64.8, 65.6, 71.8, 74.3, 78.7, 99.6, 101.9, 171.1, 171.5; HRMS (EI) calculated for $\mathrm{C}_{28} \mathrm{H}_{53} \mathrm{O}_{9} \mathrm{Si}_{2}\left(\mathrm{M}^{+}\right.$ -OMe) $\mathrm{m} / \mathrm{z}$ 589.3228, found 589.3217.

Methyl 2,3-di-O-(tert-butyldimethylsilyl)-6-deoxy-4-O-((2R)-2-(1,3-dioxolan2-yl)methyl-2-formylpropanoyl)- $\alpha$-D-glucopyranoside (18). The following reaction was carried out under Ar. To a cooled $\left(-78^{\circ} \mathrm{C}\right)$ stirred solution of 17 $(1.20 \mathrm{~g}, 1.93 \mathrm{mmol})$ in toluene $(24 \mathrm{ml})$, Dibal-H $(1.01 \mathrm{M}$ in toluene, $4.78 \mathrm{ml}$, $4.83 \mathrm{mmol}$ )was added. After being stirred at $-78^{\circ} \mathrm{C}$ for $30 \mathrm{~min}$, the mixture was quenched with $\mathrm{H}_{2} \mathrm{O}(15 \mathrm{ml})$ at $-78{ }^{\circ} \mathrm{C}$ and diluted with aqueous solution $(20 \mathrm{ml})$ of potassium sodium $(+)$-tartrate tetrahydrate $(4.09 \mathrm{~g})$ and warmed to $\mathrm{rt}$. The mixture was stirred vigorously for $2 \mathrm{~h}$, and the organic layer was separated. The aqueous layer was extracted with EtOAc $(20 \mathrm{ml} \times 3)$. The combined extracts were dried and concentrated in vacuo to provide a crude product, which was used in the next step without further purification.

The following reaction was carried out under Ar. To a stirred solution of crude product obtained above in $\mathrm{CH}_{2} \mathrm{Cl}_{2}(60 \mathrm{ml})$, MS $4 \AA$ A powder $(1.80 \mathrm{~g})$ and $\mathrm{N}$-methylmorpholine $\mathrm{N}$-oxide $(113 \mathrm{mg}, 0.965 \mathrm{mmol})$ were added. The mixture was stirred at $\mathrm{rt}$ for $10 \mathrm{~min}$ and tetrapropylammonium perruthenate $(34.0 \mathrm{mg}$, $0.097 \mathrm{mmol}$ ) was added. After being stirred at $\mathrm{rt}$ for $1 \mathrm{~h}$, the mixture was filtered through a pad of Celite and washed with EtOAc. The combined filtrate and washings were concentrated in vacuo. The residue was purified by column chromatography on silica gel (EtOAc/hexane, 1:25) to provide $973 \mathrm{mg}(88 \%)$ of 18 as a colorless oil: TLC $\mathrm{R}_{\mathrm{f}} 0.50$ (EtOAc/hexane, $\left.1: 4\right) ;[\alpha]_{\mathrm{D}}^{28}+39.0(c 1.13$, $\left.\mathrm{CHCl}_{3}\right)$; IR (neat) 2932, $1723 \mathrm{~cm}^{-1} ;{ }^{1} \mathrm{H}-\mathrm{NMR}\left(300 \mathrm{MHz}, \mathrm{CDCl}_{3}\right) \delta 0.01(\mathrm{~s}$, $3 \mathrm{H}), 0.08(\mathrm{~s}, 3 \mathrm{H}), 0.09(\mathrm{~s}, 6 \mathrm{H}), 0.82(\mathrm{~s}, 9 \mathrm{H}), 0.91(\mathrm{~s}, 9 \mathrm{H}), 1.10(\mathrm{~d}, 3 \mathrm{H}$, $J=6.3 \mathrm{~Hz}), 1.43(\mathrm{~s}, 3 \mathrm{H}), 2.22(\mathrm{dd}, 1 \mathrm{H}, J=4.4,14.4 \mathrm{~Hz}), 2.37(\mathrm{dd}, 1 \mathrm{H}, J=5.5$, $14.4 \mathrm{~Hz}$ ), $3.35(\mathrm{~s}, 3 \mathrm{H}), 3.66(\mathrm{dd}, 1 \mathrm{H}, J=3.4,8.4 \mathrm{~Hz}), 3.73(\mathrm{dd}, 1 \mathrm{H}, J=6.2$, $9.8 \mathrm{~Hz}), 3.77-3.82(\mathrm{~m}, 2 \mathrm{H}), 3.87-3.98(\mathrm{~m}, 2 \mathrm{H}), 3.91(\mathrm{t}, 1 \mathrm{H}, J=8.4 \mathrm{~Hz}), 4.60$ $(\mathrm{d}, 1 \mathrm{H}, J=3.4 \mathrm{~Hz}), 4.75(\mathrm{dd}, 1 \mathrm{H}, J=8.4,9.8 \mathrm{~Hz}), 4.98(\mathrm{dd}, 1 \mathrm{H}, J=4.4$, $5.5 \mathrm{~Hz}), 9.70(\mathrm{~s}, 1 \mathrm{H}) ;{ }^{13} \mathrm{C}-\mathrm{NMR}\left(125 \mathrm{MHz}, \mathrm{CDCl}_{3}\right) \delta-4.3,-4.1,-3.2,-2.8,17.8$ (3C), 18.5, 25.9 (3C), 26.2 (3C), 38.5, 55.0, 55.7, 64.8, 64.9, 65.3, 71.8, 74.5, 78.6, 99.7, 101.3, 171.3, 198.4; HRMS (EI) calculated for $\mathrm{C}_{26} \mathrm{H}_{49} \mathrm{O}_{8} \mathrm{Si}_{2}\left(\mathrm{M}^{+}-\right.$ OMe) $\mathrm{m} / \mathrm{z} 545.2966$, found 545.2974 .

Methyl 2,3-di-O-(tert-butyldimethylsilyl)-6-deoxy-4-O-((2 R)-2-((1,3-dioxolan-2-yl)methyl)-2-methyl-3-butenoyl)- $\alpha$-D-glucopyranoside (10). The following reaction was carried out under Ar. To a cooled $\left(-78^{\circ} \mathrm{C}\right)$ stirred solution of methyltriphenylphosphonium bromide $(1.50 \mathrm{~g}, 4.20 \mathrm{mmol})$ in THF $(50 \mathrm{ml}), n$ BuLi $(2.69 \mathrm{M}$ in hexane, $1.26 \mathrm{ml}, 3.39 \mathrm{mmol})$ was added. After being stirred at $78^{\circ} \mathrm{C}$ for $30 \mathrm{~min}$, the mixture was warmed to $0^{\circ} \mathrm{C}$ and a solution of 18 (967 mg, $1.68 \mathrm{mmol})$ in THF $(8.0 \mathrm{ml})$ was added at $0^{\circ} \mathrm{C}$. After being stirred at $0{ }^{\circ} \mathrm{C}$ for $1 \mathrm{~h}$, the mixture was quenched with saturated aqueous $\mathrm{NH}_{4} \mathrm{Cl}(30 \mathrm{ml})$ at $0{ }^{\circ} \mathrm{C}$ and extracted with EtOAc $(20 \mathrm{ml} \times 3)$. The combined extracts were dried and concentrated in vacuo. The residue was purified by column chromatography on silica gel (EtOAc/hexane, 1:30) to provide $842 \mathrm{mg}(87 \%)$ of $\mathbf{1 0}$ as a colorless oil: TLC $\mathrm{R}_{\mathrm{f}} 0.59$ (EtOAc/hexane, $\left.1: 4\right) ;[\alpha]_{\mathrm{D}}^{26}+39.5$ (c 1.07, $\mathrm{CHCl}_{3}$ ); IR (neat) 2932, $1730 \mathrm{~cm}^{-1} ;{ }^{1} \mathrm{H}-\mathrm{NMR}\left(300 \mathrm{MHz}, \mathrm{CDCl}_{3}\right) \delta 0.03(\mathrm{~s}$, $3 \mathrm{H}), 0.08(\mathrm{~s}, 3 \mathrm{H}), 0.10(\mathrm{~s}, 6 \mathrm{H}), 0.82(\mathrm{~s}, 9 \mathrm{H}), 0.92(\mathrm{~s}, 9 \mathrm{H}), 1.10(\mathrm{~d}, 3 \mathrm{H}$, $J=6.2 \mathrm{~Hz}), 1.41(\mathrm{~s}, 3 \mathrm{H}), 2.05(\mathrm{dd}, 1 \mathrm{H}, J=5.6,14.5 \mathrm{~Hz}), 2.20(\mathrm{dd}, 1 \mathrm{H}, J=3.8$, $14.5 \mathrm{~Hz}$ ), $3.37(\mathrm{~s}, 3 \mathrm{H}), 3.67(\mathrm{dd}, 1 \mathrm{H}, J=3.4,8.3 \mathrm{~Hz}), 3.73(\mathrm{dd}, 1 \mathrm{H}, J=6.2$, $9.8 \mathrm{~Hz}), 3.73-3.83(\mathrm{~m}, 2 \mathrm{H}), 3.89-3.98(\mathrm{~m}, 2 \mathrm{H}), 3.91(\mathrm{t}, 1 \mathrm{H}, J=8.3 \mathrm{~Hz}), 4.61(\mathrm{~d}$ $1 \mathrm{H}, J=3.4 \mathrm{~Hz}), 4.71(\mathrm{dd}, 1 \mathrm{H}, J=8.3,9.8 \mathrm{~Hz}), 4.84(\mathrm{dd}, 1 \mathrm{H}, J=3.8,5.6 \mathrm{~Hz})$, $5.17(\mathrm{~d}, 1 \mathrm{H}, J=17.3 \mathrm{~Hz}), 5.19(\mathrm{~d}, 1 \mathrm{H}, J=10.5 \mathrm{~Hz}), 6.03(\mathrm{dd}, 1 \mathrm{H}, J=10.5$, $17.3 \mathrm{~Hz}) ;{ }^{13} \mathrm{C}-\mathrm{NMR}\left(125 \mathrm{MHz}, \mathrm{CDCl}_{3}\right) \delta-4.3,-4.0,-3.3,-2.7,17.8,17.9,18.5$, 20.3, 26.0 (3C), 26.2 (3C), 42.2, 46.9, 54.9, 64.3, 64.7, 65.6, 71.9, 74.5, 77.8, 99.7, 102.2, 115.0, 140.5, 174.4; HRMS (EI) calculated for $\mathrm{C}_{27} \mathrm{H}_{51} \mathrm{O}_{7} \mathrm{Si}_{2}\left(\mathrm{M}^{+}-\right.$ OMe) $\mathrm{m} / \mathrm{z} 543.3173$, found 543.3172 .

(2R)-2-((1,3-dioxolan-2-yl)methyl)-2-methylbut-3-en-1-ol (19) and methyl 3-O-(tert-butyldimethylsilyl)-6-deoxy- $\alpha$-D-glucopyranoside (20). The following reaction was carried out under Ar. To a cooled $\left(-18^{\circ} \mathrm{C}\right)$ stirred solution of 10 ( $842 \mathrm{mg}, 1.46 \mathrm{mmol})$ in $\mathrm{CH}_{2} \mathrm{Cl}_{2}(17 \mathrm{ml})$, Dibal-H $(1.02 \mathrm{M}$ in toluene, $5.74 \mathrm{ml}$, $5.85 \mathrm{mmol}$ ) was added. After being stirred at $\mathrm{rt}$ for $45 \mathrm{~min}$, the mixture was quenched with $\mathrm{H}_{2} \mathrm{O}(15 \mathrm{ml})$ at $-18^{\circ} \mathrm{C}$ and diluted with aqueous solution $(25 \mathrm{ml})$ of potassium sodium $(+)$-tartrate tetrahydrate $(4.96 \mathrm{~g})$ and warmed to $\mathrm{rt}$. The mixture was stirred vigorously for $2 \mathrm{~h}$, and the organic layer was separated. The aqueous layer was extracted with EtOAc $(15 \mathrm{ml} \times 3)$. The combined extracts were dried and concentrated in vacuo. The residue was purified by column chromatography on silica gel (EtOAc/hexane, 1:15) to provide $221 \mathrm{mg}(88 \%)$ of 19 and $413 \mathrm{mg}$ of 20 (96\%). Compound 19 was obtained as a colorless oil: TLC $\mathrm{R}_{\mathrm{f}} 0.16$ (EtOAc/hexane, 1:3); $[\alpha]_{\mathrm{D}}^{27}-2.4$ (c 1.14 $\mathrm{CHCl}_{3}$ ); IR (neat) $3485,3018 \mathrm{~cm}^{-1}$; ${ }^{1} \mathrm{H}-\mathrm{NMR}\left(300 \mathrm{MHz}, \mathrm{CDCl}_{3}\right) \delta 1.07(\mathrm{~s}$, $3 \mathrm{H}), 1.77(\mathrm{dd}, 1 \mathrm{H}, J=4.8,14.5 \mathrm{~Hz}), 1.82(\mathrm{dd}, 1 \mathrm{H}, J=4.8,14.5 \mathrm{~Hz}), 3.41(\mathrm{~d}$, $1 \mathrm{H}, J=11.3 \mathrm{~Hz}$ ), $3.49(\mathrm{~d}, 1 \mathrm{H}, J=11.3 \mathrm{~Hz}), 3.82-3.86(\mathrm{~m}, 2 \mathrm{H}), 3.96-4.00(\mathrm{~m}$, $2 \mathrm{H}), 4.92(\mathrm{t}, 1 \mathrm{H}, J=4.8 \mathrm{~Hz}), 5.06(\mathrm{~d}, 1 \mathrm{H}, J=17.5 \mathrm{~Hz}), 5.10(\mathrm{~d}, 1 \mathrm{H}, J=11.0$ $\mathrm{Hz}), 5.83(\mathrm{dd}, 1 \mathrm{H}, J=11.0,17.5 \mathrm{~Hz}) ;{ }^{13} \mathrm{C}-\mathrm{NMR}\left(125 \mathrm{MHz}, \mathrm{CDCl}_{3}\right) \delta 22.2$, 40.4, 41.2, 64.7, 64.8, 69.4, 102.5, 113.4, 143.9; HRMS (EI) calcd for $\mathrm{C}_{9} \mathrm{H}_{15} \mathrm{O}_{3}$ $\left(\mathrm{M}^{+}-\mathrm{H}\right) \mathrm{m} / \mathrm{z}$ 171.1021, found 171.1024. Compound 20 was obtained as a colorless oil: TLC $\mathrm{R}_{\mathrm{f}} 0.29$ (EtOAc/hexane, 1:3); ${ }^{1} \mathrm{H}-\mathrm{NMR}\left(300 \mathrm{MHz}, \mathrm{CDCl}_{3}\right.$ ) $\delta 0.13(\mathrm{~s}, 3 \mathrm{H}), 0.16(\mathrm{~s}, 3 \mathrm{H}), 0.92(\mathrm{~s}, 9 \mathrm{H}), 1.29(\mathrm{~d}, 3 \mathrm{H}, \mathrm{J}=6.3 \mathrm{~Hz}), 1.93(\mathrm{~d}, 1 \mathrm{H}$, $\mathrm{J}=9.3 \mathrm{~Hz},-\mathrm{OH}$ at $\mathrm{C}-2), 2.12(\mathrm{~d}, 1 \mathrm{H}, \mathrm{J}=2.5 \mathrm{~Hz},-\mathrm{OH}$ at $\mathrm{C}-4), 3.12(\mathrm{dt}, 1 \mathrm{H}$ $\mathrm{J}=2.5,9.0 \mathrm{~Hz}), 3.41(\mathrm{~s}, 3 \mathrm{H}), 3.45(\mathrm{dt}, 1 \mathrm{H}, \mathrm{J}=3.9,9.3 \mathrm{~Hz}), 3.61(\mathrm{t}, 1 \mathrm{H}$, $\mathrm{J}=9.0 \mathrm{~Hz}), 3.65(\mathrm{qd}, 1 \mathrm{H}, \mathrm{J}=6.3,9.0 \mathrm{~Hz}), 4.69(\mathrm{~d}, 1 \mathrm{H}, \mathrm{J}=3.9 \mathrm{~Hz})$.

(3S)-2,3-dimethyl-4-(p-toluenesulfonyl)oxybut-1-ene (21). The following reaction was carried out under Ar. To a cooled $\left(0^{\circ} \mathrm{C}\right)$ stirred solution of $\mathrm{MeMgCl}\left(3.0 \mathrm{M}\right.$ in $\left.\mathrm{Et}_{2} \mathrm{O}, 9.96 \mathrm{ml}, 26.9 \mathrm{mmol}\right)$ in $\mathrm{Et}_{2} \mathrm{O}(30 \mathrm{ml})$, a solution of methyl (R)-(-)-3-hydroxyisobutyrate $(9)(0.90 \mathrm{ml}, 8.15 \mathrm{mmol})$ in $\mathrm{Et}_{2} \mathrm{O}(4.5 \mathrm{ml})$ was slowly added. After being stirred at rt for $1.5 \mathrm{~h}$, the mixture was quenched with aqueous $1 \mathrm{M} \mathrm{HCl}(60 \mathrm{ml})$ at $0{ }^{\circ} \mathrm{C}$ and the organic layer was separated. The aqueous layer was diluted with saturated aqueous $\mathrm{NaHCO}_{3}(100 \mathrm{ml})$ and extracted with EtOAc $(20 \mathrm{ml} \times 15)$. The combined extracts were washed with saturated aqueous $\mathrm{NaHCO}_{3}(10 \mathrm{ml})$ and saturated aqueous $\mathrm{NaCl}(10 \mathrm{ml})$. The organic layer was dried and concentrated in vacuo to provide $966 \mathrm{mg}$ of dimethylated tertiary alcohol, which was used in the next step without further purification: TLC $\mathrm{R}_{\mathrm{f}} 0.45$ (EtOAc/hexane, 2:1).

The following reaction was carried out under Ar. To a cooled $\left(0{ }^{\circ} \mathrm{C}\right)$ stirred solution of the product obtained above $(966 \mathrm{mg})$ in pyridine, $(8 \mathrm{ml}) \mathrm{TsCl}$ ( $1.90 \mathrm{~g}, 9.97 \mathrm{mmol}$ ) was added. After being stirred at $0{ }^{\circ} \mathrm{C}$ for $15 \mathrm{~h}$, the mixture was quenched with $\mathrm{H}_{2} \mathrm{O}(10 \mathrm{ml})$ at $0{ }^{\circ} \mathrm{C}$ and extracted with EtOAc $(10 \mathrm{ml} \times 3)$. The combined extracts were washed with saturated aqueous $\mathrm{KHSO}_{4}(10 \mathrm{ml})$, saturated aqueous $\mathrm{NaHCO}_{3}(10 \mathrm{ml})$ and saturated brine $(10 \mathrm{ml})$. The organic layer was dried and concentrated in vacuo to provide $2.06 \mathrm{~g}$ of monotosylate, which was used in the next step without further purification: TLC $\mathrm{R}_{\mathrm{f}} 0.63$ (EtOAc/hexane, 2:1); ${ }^{1} \mathrm{H}-\mathrm{NMR}\left(300 \mathrm{MHz}, \mathrm{CDCl}_{3}\right) \delta 0.95(\mathrm{~d}, 3 \mathrm{H}, J=7.2 \mathrm{~Hz})$ $1.11(\mathrm{~s}, 3 \mathrm{H}), 1.18(\mathrm{~s}, 3 \mathrm{H}), 1.81-1.87(\mathrm{~m}, 1 \mathrm{H}), 2.44(\mathrm{~s}, 3 \mathrm{H}), 3.91(\mathrm{dd}, 1 \mathrm{H}$, $J=7.8,9.5 \mathrm{~Hz}), 4.23(\mathrm{dd}, 1 \mathrm{H}, J=4.4,9.5 \mathrm{~Hz}), 7.34(\mathrm{~d}, 2 \mathrm{H}, J=8.4 \mathrm{~Hz}), 7.79(\mathrm{~d}$, $2 \mathrm{H}, J=8.4 \mathrm{~Hz}$ )

The following reaction was carried out under Ar. To a stirred solution of monotosylate obtained above $(2.06 \mathrm{~g})$ in $\mathrm{Et}_{2} \mathrm{O}(60 \mathrm{ml}), \mathrm{MsCl}(1.29 \mathrm{ml}$ $16.7 \mathrm{mmol})$ was added. Then $\mathrm{Et}_{3} \mathrm{~N}(15.8 \mathrm{ml}, 113 \mathrm{mmol})$ was added slowly at $0{ }^{\circ} \mathrm{C}$. After being stirred at $\mathrm{rt}$ for $15 \mathrm{~h}$, the mixture was quenched with aqueous $1 \mathrm{M} \mathrm{HCl}(60 \mathrm{ml})$ at $0{ }^{\circ} \mathrm{C}$ and extracted with EtOAc $(30 \mathrm{ml} \times 3)$. The combined extracts were washed with aqueous $1 \mathrm{M} \mathrm{HCl}(30 \mathrm{ml})$, saturated aqueous $\mathrm{NaHCO}_{3}(30 \mathrm{ml})$ and saturated brine $(30 \mathrm{ml})$. The organic layer was dried and concentrated in vacuo. The residue was purified by column chromatography on silica gel (EtOAc/hexane, 1:15) to provide $1.15 \mathrm{~g}$ (56\% over three steps) of 21 as a colorless oil: TLC $\mathrm{R}_{\mathrm{f}} 0.60$ (EtOAc/hexane, 1:4); $[\alpha]_{\mathrm{D}}^{27}+7.4(c$ $\left.0.910, \mathrm{CHCl}_{3}\right)$; IR (neat) 2974, $1649 \mathrm{~cm}^{-1} ;{ }^{1} \mathrm{H}-\mathrm{NMR}\left(300 \mathrm{MHz}, \mathrm{CDCl}_{3}\right) \delta 1.02$ $(\mathrm{d}, 3 \mathrm{H}, J=6.9 \mathrm{~Hz}), 1.62(\mathrm{~d}, 3 \mathrm{H}, J=0.6 \mathrm{~Hz}), 2.47(\mathrm{~m}, 1 \mathrm{H}), 2.45(\mathrm{~s}, 3 \mathrm{H}), 3.86$ $(\mathrm{dd}, 1 \mathrm{H}, J=7.1,9.5 \mathrm{~Hz}), 3.99(\mathrm{dd}, 1 \mathrm{H}, J=6.6,9.5 \mathrm{~Hz}), 4.69(\mathrm{~m}, 1 \mathrm{H}), 4.78(\mathrm{~m}$, $1 \mathrm{H}), 7.34(\mathrm{~d}, 2 \mathrm{H}, J=8.3 \mathrm{~Hz}), 7.78(\mathrm{~d}, 2 \mathrm{H}, J=8.3 \mathrm{~Hz}) ;{ }^{13} \mathrm{C}-\mathrm{NMR}(125 \mathrm{MHz}$, $\left.\mathrm{CDCl}_{3}\right) \delta 15.9,20.1,21.6,40.1,73.1,112.0,127.9(2 \mathrm{C}), 129.8(2 \mathrm{C}), 133.1$ 144.6, 144.9; HRMS (EI) calculated for $\mathrm{C}_{13} \mathrm{H}_{18} \mathrm{O}_{3} \mathrm{~S}\left(\mathrm{M}^{+}\right) \mathrm{m} / z 254.0977$ found 254.0981 .

(3S)-4-bromo-2,3-dimethylbut-1-ene (22). The following reaction was carried out under Ar. To a stirred solution of $21(2.60 \mathrm{~g}, 10.2 \mathrm{mmol})$ in THF $(26 \mathrm{ml})$ $\mathrm{LiBr}(3.55 \mathrm{~g} \mathrm{~g}, 40.8 \mathrm{mmol})$ was added. After being stirred under reflux for $3.5 \mathrm{~h}$ the mixture was cooled to $\mathrm{rt}$, diluted with $\mathrm{Et}_{2} \mathrm{O}(50 \mathrm{ml})$, and washed with saturated aqueous $\mathrm{NH}_{4} \mathrm{Cl}(80 \mathrm{ml} \times 3)$ and saturated brine $(80 \mathrm{ml})$. The organic layer was dried and concentrated by distillation to provide 
$1.67 \mathrm{~g}$ of crude 22 , which was used in the next step without further purification: TLC $\mathrm{R}_{\mathrm{f}} 0.78$ (EtOAc/hexane, $\left.1: 10\right) ;{ }^{1} \mathrm{H}-\mathrm{NMR}\left(300 \mathrm{MHz}, \mathrm{CDCl}_{3}\right.$ ) $\delta 1.17(\mathrm{~d}, 3 \mathrm{H}, J=6.9 \mathrm{~Hz}), 1.72(\mathrm{~s}, 3 \mathrm{H}), 2.50-2.57(\mathrm{~m}, 1 \mathrm{H}), 3.33(\mathrm{dd}, 1 \mathrm{H}$, $J=7.4,9.8 \mathrm{~Hz}), 3.44(\mathrm{dd}, 1 \mathrm{H}, J=6.2,9.8 \mathrm{~Hz}), 4.78-4.79(\mathrm{~m}, 1 \mathrm{H}), 4.84-4.86$ $(\mathrm{m}, 1 \mathrm{H})$.

(2R)-2-((1,3-dioxolan-2-yl)methyl)-2-methylbut-3-enal (7). To a cooled $\left(0^{\circ} \mathrm{C}\right)$ stirred solution of $19(390 \mathrm{mg}, 2.27 \mathrm{mmol})$ in $\mathrm{CH}_{2} \mathrm{Cl}_{2}(8 \mathrm{ml}), \mathrm{NaHCO}_{3}$ $(572 \mathrm{mg}, 6.81 \mathrm{mmol})$ and Dess-Martin periodinane $(1.44 \mathrm{~g}, 3.41 \mathrm{mmol})$ were added. After being stirred at $\mathrm{rt}$ for $1 \mathrm{~h}$, the mixture was quenched with saturated aqueous $\mathrm{NaHCO}_{3} / 20 \mathrm{wt} \%$ aqueous $\mathrm{Na}_{2} \mathrm{~S}_{2} \mathrm{O}_{3}(1: 1,20 \mathrm{ml})$ at $0{ }^{\circ} \mathrm{C}$ and extracted with $\mathrm{CH}_{2} \mathrm{Cl}_{2}(10 \mathrm{ml} \times 3)$. The combined extracts were dried and concentrated in vacuo. The residue was purified by column chromatography on silica gel (EtOAc/hexane, 1:15) to provide $370 \mathrm{mg}(96 \%)$ of 7 as a colorless oil: TLC $\mathrm{R}_{\mathrm{f}} 0.71$ (EtOAc/hexane, 1:1); [ $\left.\alpha\right]_{\mathrm{D}}^{26}+6.0\left(c 0.990, \mathrm{CHCl}_{3}\right)$; IR (neat) 3020 , $1727 \mathrm{~cm}^{-1} ;{ }^{1} \mathrm{H}-\mathrm{NMR}\left(300 \mathrm{MHz}, \mathrm{CDCl}_{3}\right) \delta 1.26(\mathrm{~s}, 3 \mathrm{H}), 1.99(\mathrm{dd}, 1 \mathrm{H}, J=4.5$, $14.4 \mathrm{~Hz}), 2.06(\mathrm{dd}, 1 \mathrm{H}, J=5.5,14.4 \mathrm{~Hz}), 3.78-3.83(\mathrm{~m}, 2 \mathrm{H}), 3.92-3.96(\mathrm{~m}$, $2 \mathrm{H}), 4.91(\mathrm{dd}, 1 \mathrm{H}, J=4.5,5.5 \mathrm{~Hz}), 5.16(\mathrm{~d}, 1 \mathrm{H}, J=17.6 \mathrm{~Hz}), 5.27(\mathrm{~d}, 1 \mathrm{H}$, $J=10.8 \mathrm{~Hz}), 5.83(\mathrm{dd}, 1 \mathrm{H}, \quad J=10.8,17.6 \mathrm{~Hz}), 9.38(\mathrm{~s}, 1 \mathrm{H}) ;{ }^{13} \mathrm{C}-\mathrm{NMR}$ $\left(125 \mathrm{MHz}, \mathrm{CDCl}_{3}\right) \delta 18.7,39.9,50.7,64.8,64.9,101.9,116.7,138.4,201.5$; HRMS (EI) calculated for $\mathrm{C}_{9} \mathrm{H}_{14} \mathrm{O}_{3}\left(\mathrm{M}^{+}\right) \mathrm{m} / z$ 170.0943, found 170.0944.

1:1 mixture of (3R,4R and S,6R)-3-[(1,3-dioxolan-2-yl)methyl]-3,6,7-trimethylocta- 1,7-dien-4-ols (23). The following reaction was carried out under Ar. To magnesium turnings $(372 \mathrm{mg}, 10.2 \mathrm{mmol})$ soaked with THF $(8 \mathrm{ml})$ were added 1,2-dibromoethane $(131 \mu \mathrm{l}, 1.53 \mathrm{mmol})$ and a solution of crude 22 obtained above $(1.67 \mathrm{~g})$ in THF $(2 \mathrm{ml})$. The mixture was stirred under reflux for $1 \mathrm{~h}$, and a solution of $7(370 \mathrm{mg}, 2.17 \mathrm{mmol})$ in THF $(3 \mathrm{ml})$ was added. After being stirred at $\mathrm{rt}$ for $1 \mathrm{~h}$, the mixture was quenched with saturated aqueous $\mathrm{NH}_{4} \mathrm{Cl}(20 \mathrm{ml})$ at $0{ }^{\circ} \mathrm{C}$ and extracted with EtOAc $(10 \mathrm{ml} \times 3)$. The combined extracts were washed with saturated brine $(10 \mathrm{ml})$, dried and concentrated in vacuo. The residue was purified by column chromatography on silica gel (EtOAc/hexane, 1:20) to provide $326 \mathrm{mg}(59 \%)$ of 23 as a ca. 1:1 diastereomeric mixture and $135 \mathrm{mg}(36 \%)$ of 19. Compound 23 was obtained as a colorless oil: TLC $\mathrm{R}_{\mathrm{f}} 0.24$ (EtOAc/hexane, 1:4); $[\alpha]_{\mathrm{D}}^{27}-6.5\left(c 1.31, \mathrm{CHCl}_{3}\right)$; IR (neat) 3491, $2965 \mathrm{~cm}^{-1} ;{ }^{1} \mathrm{H}-\mathrm{NMR}\left(500 \mathrm{MHz}, \mathrm{CDCl}_{3}\right) \delta 1.01(\mathrm{~d}, 3 \mathrm{H} \times 1 / 2$, $J=6.9 \mathrm{~Hz}), 1.02(\mathrm{~d}, 3 \mathrm{H} \times 1 / 2, J=6.9 \mathrm{~Hz}), 1.04(\mathrm{~s}, 3 \mathrm{H} \times 1 / 2), 1.06(\mathrm{~s}, 3 \mathrm{H} \times 1 /$ 2), $1.33-1.51(\mathrm{~m}, 2 \mathrm{H}), 1.61(\mathrm{~s}, 3 \mathrm{H} \times 1 / 2), 1.68-1.77(\mathrm{~m}, 1 \mathrm{H}), 1.71(\mathrm{~s}, 3 \mathrm{H} \times 1 /$ 2), $1.83-1.94(\mathrm{~m}, 1 \mathrm{H}), 2.33-2.39(\mathrm{~m}, 1 \mathrm{H} \times 1 / 2), 2.48-2.58(\mathrm{~m}, 1 \mathrm{H} \times 1 / 2), 3.28$ (d, $1 \mathrm{H} \times 1 / 2, J=10.5 \mathrm{~Hz}), 3.28(\mathrm{~d}, 1 \mathrm{H} \times 1 / 2, J=10.5 \mathrm{~Hz}), 3.80-3.90(\mathrm{~m}, 2 \mathrm{H})$, 3.93-4.10 (m, 2H), 4.67-4.69 (m, $1 \mathrm{H}), 4.73-4.74(\mathrm{~m}, 1 \mathrm{H}), 4.90(\mathrm{dd}, 1 \mathrm{H} \times 1 / 2$, $J=2.7,6.7 \mathrm{~Hz}), 4.93(\mathrm{dd}, 1 \mathrm{H} \times 1 / 2, J=4.0,5.5 \mathrm{~Hz}), 5.03(\mathrm{dd}, 1 \mathrm{H} \times 1 / 2$, $J=1.3,17.5 \mathrm{~Hz}), 5.07(\mathrm{dd}, 1 \mathrm{H} \times 1 / 2, J=1.2,17.0 \mathrm{~Hz}), 5.12(\mathrm{dd}, 1 \mathrm{H} \times 1 / 2$, $J=1.3,10.9 \mathrm{~Hz}), 5.13(\mathrm{dd}, 1 \mathrm{H} \times 1 / 2, J=1.2,11.0 \mathrm{~Hz}), 5.85(\mathrm{dd}, 1 \mathrm{H} \times 1 / 2$, $J=10.9,17.5 \mathrm{~Hz}), 5.87(\mathrm{dd}, 1 \mathrm{H} \times 1 / 2, J=11.0,17.0 \mathrm{~Hz}) ;{ }^{13} \mathrm{C}-\mathrm{NMR}(125 \mathrm{MHz}$, $\left.\mathrm{CDCl}_{3}\right) \delta 18.1(1 / 2 \mathrm{C}), 18.6(1 / 2 \mathrm{C}), 18.7(1 / 2 \mathrm{C}), 19.4(1 / 2 \mathrm{C}), 19.9(1 / 2 \mathrm{C})$, 20.8 (1/2C), 36.1 (1/2C), $37.1(1 / 2 \mathrm{C}), 38.0(1 / 2 \mathrm{C}), 38.2(1 / 2 \mathrm{C}), 41.3(1 / 2 \mathrm{C})$, $42.6(1 / 2 \mathrm{C}), 43.1(1 / 2 \mathrm{C}), 43.2(1 / 2 \mathrm{C}), 64.4(1 / 2 \mathrm{C}), 64.6(1 / 2 \mathrm{C}), 64.8(1 / 2 \mathrm{C})$, 65.0 (1/2C), $74.4(1 / 2 \mathrm{C}), 74.6(1 / 2 \mathrm{C}), 102.5$ (1/2C), 102.7 (1/2C), $108.7(1 / 2 \mathrm{C})$, $110.6(1 / 2 \mathrm{C}), \quad 113.8, \quad 143.7$ (1/2C), 143.8 (1/2C), 149.0 (1/2C), 151.7 (1/2C); HRMS (EI) calculated for $\mathrm{C}_{15} \mathrm{H}_{26} \mathrm{O}_{3}\left(\mathrm{M}^{+}\right) \mathrm{m} / \mathrm{z} 254.1882$, found 254.1894 .

(3R,6R)-3-[(1,3-dioxolan-2-yl)methyl]-3,6,7-trimethylocta-1,7-dien-4-one (6). To a cooled $\left(0{ }^{\circ} \mathrm{C}\right)$, stirred solution of the mixture $23(326 \mathrm{mg}, 1.28 \mathrm{mmol})$ in $\mathrm{CH}_{2} \mathrm{Cl}_{2}(6.5 \mathrm{ml})$ were added $\mathrm{NaHCO}_{3}(323 \mathrm{mg}, 3.84 \mathrm{mmol})$ and DessMartin periodinane $(815 \mathrm{mg}, 1.92 \mathrm{mmol})$. The mixture was stirred at $\mathrm{rt}$ for $1 \mathrm{~h}$, and then quenched with $20 \%$ aqueous $\mathrm{Na}_{2} \mathrm{~S}_{2} \mathrm{O}_{3}(15 \mathrm{ml})$. The mixture was stirred vigorously for $1 \mathrm{~h}$, and extracted with $\mathrm{CH}_{2} \mathrm{Cl}_{2}(10 \mathrm{ml} \times 4)$. The combined extracts were dried and concentrated in vacuo. The residue was purified by column chromatography on silica gel (EtOAc/hexane, 1:30) to provide $281 \mathrm{mg}(87 \%)$ of $\mathbf{6}$ as a colorless oil: TLC $\mathrm{R}_{\mathrm{f}} 0.59$ (EtOAc/hexane, 1:4); $[\alpha]_{\mathrm{D}}^{32}-33.7$ (c 0.990, $\mathrm{CHCl}_{3}$ ); IR (neat) 2969, $1708 \mathrm{~cm}^{-1}$; ${ }^{1} \mathrm{H}-\mathrm{NMR}(300 \mathrm{MHz}$, $\left.\mathrm{CDCl}_{3}\right) \delta 0.97(\mathrm{~d}, 3 \mathrm{H}, J=6.9 \mathrm{~Hz}), 1.30(\mathrm{~s}, 3 \mathrm{H}), 1.69(\mathrm{~s}, 3 \mathrm{H}), 2.06(\mathrm{~d}, 2 \mathrm{H}$, $J=4.9 \mathrm{~Hz}), 2.45(\mathrm{dd}, 1 \mathrm{H}, J=7.6,17.3 \mathrm{~Hz}), 2.61(\mathrm{dd}, 1 \mathrm{H}, J=5.1,17.3 \mathrm{~Hz})$, 2.64-2.76 (m, 1H), 3.58-3.80 (m, 2H), 3.90-3.95 (m, 2H), $4.67(\mathrm{~s}, 2 \mathrm{H}), 4.84(\mathrm{t}$, $1 \mathrm{H}, J=4.9 \mathrm{~Hz}), 5.18(\mathrm{~d}, 1 \mathrm{H}, J=17.5 \mathrm{~Hz}), 5.22(\mathrm{~d}, 1 \mathrm{H}, J=10.5 \mathrm{~Hz}), 5.92(\mathrm{dd}$, $1 \mathrm{H}, J=10.5,17.5 \mathrm{~Hz}) ;{ }^{13} \mathrm{C}-\mathrm{NMR}\left(125 \mathrm{MHz}, \mathrm{CDCl}_{3}\right) \delta 19.4,20.3,20.4,35.6$, $41.1,43.4,52.3,64.5,64.7,102.3,109.0,115.3,141.1,149.7,210.4$; HRMS (EI) calculated for $\mathrm{C}_{15} \mathrm{H}_{24} \mathrm{O}_{3}\left(\mathrm{M}^{+}\right) \mathrm{m} / z$ 252.1726, found 252.1729.
(2R,5R)-2-((1,3-dioxolan-2-yl)methyl)-2,4,5-trimethylcycohex-3-en-1-one (5). The following reaction was carried out under Ar. To a stirred solution of $\mathbf{6}$ $(305 \mathrm{mg}, 1.21 \mathrm{mmol})$ in degassed toluene $(62 \mathrm{ml})$, Grubbs 2nd generation catalyst $24(54 \mathrm{mg}, 0.060 \mathrm{mmol})$ was added. After being stirred at $80^{\circ} \mathrm{C}$ for $18 \mathrm{~h}$, the mixture was cooled to $\mathrm{rt}$ and concentrated in vacuo. The residue was purified by column chromatography on silica gel (EtOAc/hexane, 1:30) to provide $245 \mathrm{mg}(90 \%)$ of $\mathbf{5}$ and $22 \mathrm{mg}$ (7\%) of recovered $\mathbf{6}$. Compound $\mathbf{5}$ was obtained as a colorless oil: TLC $\mathrm{R}_{\mathrm{f}} 0.36$ (EtOAc/hexane, $\left.1: 4\right) ;[\alpha]_{\mathrm{D}}^{26}+103.3(c$ $\left.1.00, \mathrm{CHCl}_{3}\right)$; IR (neat) $2965,1714 \mathrm{~cm}^{-1}$; ${ }^{1} \mathrm{H}-\mathrm{NMR}\left(300 \mathrm{MHz}, \mathrm{CDCl}_{3}\right) \delta 1.07$ $(\mathrm{d}, 3 \mathrm{H}, J=7.2 \mathrm{~Hz}), 1.14(\mathrm{~s}, 3 \mathrm{H}), 1.73(\mathrm{dd}, 1 \mathrm{H}, J=4.1,14.1 \mathrm{~Hz}), 1.77$ (d, $3 \mathrm{H}$, $J=0.6 \mathrm{~Hz}), 2.16(\mathrm{dd}, 1 \mathrm{H}, J=6.0,14.1 \mathrm{~Hz}), 2.31(\mathrm{dd}, 1 \mathrm{H}, J=5.0,14.0 \mathrm{~Hz})$, 2.45-2.56 (m, 1H), $2.73(\mathrm{dd}, 1 \mathrm{H}, J=6.4,14.0 \mathrm{~Hz}), 3.73-3.79(\mathrm{~m}, 2 \mathrm{H}), 3.87-$ $3.94(\mathrm{~m}, 2 \mathrm{H}), 4.84(\mathrm{dd}, 1 \mathrm{H}, J=4.1,6.0 \mathrm{~Hz}), 5.25($ br s, $1 \mathrm{H}) ;{ }^{13} \mathrm{C}-\mathrm{NMR}$ $\left(125 \mathrm{MHz}, \mathrm{CDCl}_{3}\right) \delta 19.6,21.3,26.9,36.2,42.4,44.4,46.2,64.4,64.6,102.4$, 128.1, 137.5, 213.8; HRMS (EI) calculated for $\mathrm{C}_{13} \mathrm{H}_{20} \mathrm{O}_{3}\left(\mathrm{M}^{+}\right) \mathrm{m} / \mathrm{z} 224.1413$, found 224.1414 .

$(1 S, 2 R, 5 R)-2-((1,3-D i o x o l a n-2-y l)$ methyl $)-1([2-($ ethoxycarbonyl)ethynyl)2,4,5-trimethylcyclohex-3-en-1-ol (4). The following reaction was carried out under Ar. To a cooled $\left(-78^{\circ} \mathrm{C}\right)$ stirred solution of ethyl propiolate $(0.087 \mathrm{ml}, 0.90 \mathrm{mmol})$ in THF $(0.5 \mathrm{ml}) n$-BuLi $(2.69 \mathrm{M}$ in hexane, $0.34 \mathrm{ml}$, $0.92 \mathrm{mmol}$ ) was added. The mixture was stirred at $-78^{\circ} \mathrm{C}$ for $1 \mathrm{~h}$, and a solution of $5(27.6 \mathrm{mg}, 0.123 \mathrm{mmol})$ in THF $(1.3 \mathrm{ml})$ was added. After being stirred at $-78{ }^{\circ} \mathrm{C}$ for $1.5 \mathrm{~h}$, the mixture was quenched with saturated aqueous $\mathrm{NH}_{4} \mathrm{Cl}(5 \mathrm{ml})$ at $-78{ }^{\circ} \mathrm{C}$ and extracted with EtOAc $(5 \mathrm{ml} \times 3)$. The combined extracts were dried and concentrated in vacuo. The residue was purified by column chromatography on silica gel (EtOAc/hexane, 1:20) to provide $34.1 \mathrm{mg}(86 \%)$ of 4 as a colorless oil: TLC $\mathrm{R}_{\mathrm{f}} 0.39$ (EtOAc/hexane, $1: 2) ;[\alpha]_{\mathrm{D}}^{25}+7.8\left(c 1.07, \mathrm{CHCl}_{3}\right)$; IR (neat) $3437,3020,2233,1707 \mathrm{~cm}^{-1}$; ${ }^{1} \mathrm{H}-\mathrm{NMR}\left(300 \mathrm{MHz}, \mathrm{CDCl}_{3}\right) \delta 1.07(\mathrm{~d}, 3 \mathrm{H}, J=7.2 \mathrm{~Hz}), 1.29(\mathrm{~s}, 3 \mathrm{H}), 1.30(\mathrm{t}$, $3 \mathrm{H}, J=7.1 \mathrm{~Hz}), 1.67(\mathrm{~s}, 3 \mathrm{H}), 1.83(\mathrm{dd}, 1 \mathrm{H}, J=8.7,13.2 \mathrm{~Hz}), 1.85-1.90(\mathrm{~m}$, $2 \mathrm{H}), 2.07(\mathrm{dd}, 1 \mathrm{H}, J=6.6,13.2 \mathrm{~Hz}), 2.35-2.40(\mathrm{~m}, 1 \mathrm{H}), 3.35$ (br s, $1 \mathrm{H})$, 3.81-3.88 (m, 2H), 3.95-4.01 (m, 2H), $4.21(\mathrm{q}, 2 \mathrm{H}, J=7.1 \mathrm{~Hz}), 5.00(\mathrm{dd}$, $1 \mathrm{H}, J=4.3,5.4 \mathrm{~Hz}), 5.07(\mathrm{~s}, 1 \mathrm{H}) ;{ }^{13} \mathrm{C}-\mathrm{NMR}\left(125 \mathrm{MHz}, \mathrm{CDCl}_{3}\right) \delta 14.0,19.2$, 21.0, 23.8, 33.6, 41.1, 41.6, 42.2, 61.9, 64.6, 64.9, 73.7, 76.4, 89.8, 102.6, $128.4,136.6$, 153.6; HRMS (EI) calculated for $\mathrm{C}_{18} \mathrm{H}_{26} \mathrm{O}_{5}\left(\mathrm{M}^{+}\right) \mathrm{m} / \mathrm{z}$ 322.1780 , found 322.1775 .

(5R,6R,9R)-6-((1,3-dioxolan-2-yl)methyl)-6,8,9-trimethyl-1-oxaspiro[4.5] deca-3,7-dien-2-one (25). To a stirred solution of $4(4.8 \mathrm{mg}, 0.015 \mathrm{mmol})$ in EtOAc $(1 \mathrm{ml})$, Lindlar catalyst $(1.0 \mathrm{mg})$ under Ar was added, and then the atmosphere was replaced to $\mathrm{H}_{2}$. The mixture was stirred for $1.5 \mathrm{~h}$ under $\mathrm{H}_{2}$, filtered through a pad of Celite, and washed well with EtOAc. The combined filtrate and washings were concentrated in vacuo. The residue was purified by column chromatography on silica gel (EtOAc/hexane, 1:20) to provide $3.1 \mathrm{mg}$ (74\%) of $\mathbf{2 5}$ as a colorless oil: TLC $\mathrm{R}_{\mathrm{f}} 0.52$ (EtOAc/hexane, 1:2); IR (neat) 3020 , $1755 \mathrm{~cm}^{-1}$; ${ }^{1} \mathrm{H}-\mathrm{NMR}\left(500 \mathrm{MHz}, \mathrm{CDCl}_{3}\right) \delta 0.90(\mathrm{~s}, 3 \mathrm{H}), 1.09(\mathrm{~d}, 3 \mathrm{H}, J=7.2$ $\mathrm{Hz}), 1.66(\mathrm{dd}, 1 \mathrm{H}, J=6.3,12.8 \mathrm{~Hz}), 1.71(\mathrm{~s}, 3 \mathrm{H}), 1.93(\mathrm{dd}, 1 \mathrm{H}, J=6.3,14.3 \mathrm{~Hz})$, 1.99 (dd, $1 \mathrm{H}, J=4.0,14.3 \mathrm{~Hz}), 2.15$ (dd, $1 \mathrm{H}, J=10.6,12.8 \mathrm{~Hz}), 2.19-2.25$ (m, $1 \mathrm{H}), 3.78-3.86(\mathrm{~m}, 2 \mathrm{H}), 3.92-3.98(\mathrm{~m}, 2 \mathrm{H}), 5.00(\mathrm{dd}, 1 \mathrm{H}, J=4.0,6.3 \mathrm{~Hz}), 5.29$ $(\mathrm{s}, 1 \mathrm{H}), 6.05(\mathrm{~d}, 1 \mathrm{H}, J=5.7 \mathrm{~Hz}), 7.46(\mathrm{~d}, 1 \mathrm{H}, J=5.7 \mathrm{~Hz}) ;{ }^{13} \mathrm{C}-\mathrm{NMR}(125 \mathrm{MHz}$, $\left.\mathrm{CDCl}_{3}\right) \delta 19.5,20.9,22.1,34.5,38.3,39.4,43.0,64.4,64.7,92.9,102.8,121.0$, 128.6, 136.3, 159.5, 172.5; HRMS (EI) calculated for $\mathrm{C}_{16} \mathrm{H}_{22} \mathrm{O}_{4}\left(\mathrm{M}^{+}\right) \mathrm{m} / \mathrm{z}$ 278.1518, found 278.1513 .

(5S,6R,9R)-6-((1,3-dioxolan-2-yl)methyl)-4-methoxy-6,8,9-trimethyl-1-oxaspiro [4.5]deca-3,7-dien-2-one (3) and (1S,2R,5R)-2-((1,3-dioxolan-2-yl)methyl)-1((Z)-1-methoxy-2-(ethoxycarbonyl)ethenyl)-2,4,5-trimethylcyclohex-3-en-1-ol (26). The following reaction was carried out under Ar. To a stirred solution of $4(34.6 \mathrm{mg}, 0.107 \mathrm{mmol})$ and MS $3 \mathrm{~A}$ powder $(200 \mathrm{mg})$ in $\mathrm{MeOH}(1.0 \mathrm{ml})$ was added $\mathrm{NaOMe}(1.0 \mathrm{M}$ in $\mathrm{MeOH}, 0.27 \mathrm{ml}, 0.27 \mathrm{mmol})$. After being stirred at $\mathrm{rt}$ for $18 \mathrm{~h}$, the mixture was warmed to $60^{\circ} \mathrm{C}$. The mixture was stirred at $60{ }^{\circ} \mathrm{C}$ for $16.5 \mathrm{~h}$, quenched with saturated aqueous $\mathrm{NH}_{4} \mathrm{Cl}(5 \mathrm{ml})$ and extracted with EtOAc $(5 \mathrm{ml} \times 3)$. The combined extracts were dried and concentrated in vacuo. The residue was purified by column chromatography on silica gel (EtOAc/hexane, 1:10) to provide $9.2 \mathrm{mg}(28 \%)$ of $\mathbf{3}$ and $7.5 \mathrm{mg}$ of $\mathbf{2 6}(21 \%)$. Compound 3 was obtained as a colorless oil: TLC $\mathrm{R}_{\mathrm{f}} 0.17$ (EtOAc/hexane, 1:2); $[\alpha]_{\mathrm{D}}^{26}+11.1\left(\mathrm{c} 0.465, \mathrm{CHCl}_{3}\right.$ ); IR (neat) $3020,1745,1627 \mathrm{~cm}^{-1}$; ${ }^{1} \mathrm{H}-\mathrm{NMR}$ $\left(500 \mathrm{MHz}, \mathrm{CDCl}_{3}\right) \delta 0.97(\mathrm{~s}, 3 \mathrm{H}), 1.05(\mathrm{~d}, 3 \mathrm{H}, J=6.9 \mathrm{~Hz}), 1.68(\mathrm{~s}, 3 \mathrm{H}), 1.88$ (dd, $1 \mathrm{H}, J=6.5,14.0 \mathrm{~Hz}), 1.89$ (dd, $1 \mathrm{H}, J=6.2,14.3 \mathrm{~Hz}$ ), $1.93(\mathrm{dd}, 1 \mathrm{H}, J=3.8$, 
$14.3 \mathrm{~Hz}), 2.05(\mathrm{dd}, 1 \mathrm{H}, J=9.7,14.0 \mathrm{~Hz}), 2.33-2.41(\mathrm{~m}, 1 \mathrm{H}), 3.77-3.86(\mathrm{~m}, 2 \mathrm{H})$, $3.79(\mathrm{~s}, 3 \mathrm{H}), 3.91-3.96(\mathrm{~m}, 2 \mathrm{H}), 5.01(\mathrm{~s}, 1 \mathrm{H}), 5.02(\mathrm{dd}, 1 \mathrm{H}, J=3.8,6.2 \mathrm{~Hz})$, 5.19 (s, 1H); ${ }^{13} \mathrm{C}-\mathrm{NMR}\left(125 \mathrm{MHz}, \mathrm{CDCl}_{3}\right) \delta 19.5,21.0,21.2,32.6,37.4,39.1$, 43.2, 59.2, 64.3, 64.7, 88.2, 89.1, 102.8, 126.9, 136.7, 171.8, 185.8; HRMS (EI) calculated for $\mathrm{C}_{17} \mathrm{H}_{24} \mathrm{O}_{5}\left(\mathrm{M}^{+}\right) \mathrm{m} / \mathrm{z} 308.1624$, found 308.1633. Compound 26 was obtained as a colorless oil: TLC $\mathrm{R}_{\mathrm{f}} 0.59$ (EtOAc/hexane, 1:2); $[\alpha]_{\mathrm{D}}^{21}+33.8$ (c $0.575, \mathrm{CHCl}_{3}$ ); IR (neat) 3462, 3020, 1708, $1626 \mathrm{~cm}^{-1}$; ${ }^{1} \mathrm{H}-\mathrm{NMR}(500 \mathrm{MHz}$, $\left.\mathrm{CDCl}_{3}\right) \delta 0.99(\mathrm{~s}, 3 \mathrm{H}), 1.11(\mathrm{~d}, 3 \mathrm{H}, J=7.0 \mathrm{~Hz}), 1.61(\mathrm{dd}, 1 \mathrm{H}, J=4.6,13.8 \mathrm{~Hz})$, $1.70(\mathrm{~s}, 3 \mathrm{H}), 1.74(\mathrm{dd}, 1 \mathrm{H}, J=3.2,14.9 \mathrm{~Hz}), 2.00(\mathrm{dd}, 1 \mathrm{H}, J=6.0,14.9 \mathrm{~Hz})$, $2.22(\mathrm{dd}, 1 \mathrm{H}, J=7.3,13.8 \mathrm{~Hz}), 2.25-2.30(\mathrm{~m}, 1 \mathrm{H}), 3.34(\mathrm{~s}, 1 \mathrm{H}), 3.68(\mathrm{~s}, 3 \mathrm{H})$, 3.80-3.89 (m, $2 \mathrm{H}), 3.91(\mathrm{~s}, 3 \mathrm{H}), 3.95-4.00(\mathrm{~m}, 2 \mathrm{H}), 4.99(\mathrm{dd}, 1 \mathrm{H}, J=3.2$, $6.0 \mathrm{~Hz}), 5.17(\mathrm{~s}, 1 \mathrm{H}), 5.60(\mathrm{~s}, 1 \mathrm{H}) ;{ }^{13} \mathrm{C}-\mathrm{NMR}\left(125 \mathrm{MHz}, \mathrm{CDCl}_{3}\right) \delta 20.5,21.6$ 25.7, 33.0, 38.8, 41.7, 42.6, 51.0, 62.4, 64.7, 64.8, 78.0, 95.8, 103.2, 128.1, 136.3 166.2, 176.0; HRMS (EI) calculated for $\mathrm{C}_{18} \mathrm{H}_{27} \mathrm{O}_{6}\left(\mathrm{M}^{+}-\mathrm{H}\right) \mathrm{m} / \mathrm{z} 339.1808$, found 339.1810 .

1 Park, H.-R., Furihata, K., Hayakawa, Y. \& Shin-ya, K. Versipelostatin, a novel GRP78/ Bip molecular chaperone down-regulator of microbial origin. Tetrahedron Lett. 43, 6941-6845 (2002)

2 Shin-ya, K., Park, H.-R., Chijiwa, S., Hayakawa, Y. \& Furihata, K. Studies on the inhibitor of molecular chaperon GRP78 expression, versipelostatin. Abstracts of papers of the 45th symposium on natural product chemistry, page 157, Kyoto (2003).

3 Park, H.-R., Chijiwa, S., Furihata, K., Hayakawa, Y. \& Shin-ya, K. Relative and absolute configuration of versipelostatin, a down-regulator of molecular chaperone GRP78 expression. Org. Lett. 9, 1457-1460 (2007).

4 Chijiwa, S. et al. Biosynthetic studies of versipelostatin, a novel 17-membered $\alpha$ tetronic acid involved macrocyclic compound isolated from Streptomyces versipellis. Tetrahedron Lett. 44, 5897-5900 (2003).

5 Kunst, E. \& Kirschning, A. Total synthesis of the trisaccharide unit of the molecular chaperone down-regulator versipelostatin. Synthesis 2397-2403 (2006).

6 Tanaka, H. et al. Efficient synthesis of the deoxysugar part of versipelostatin by direct and stereoselective glycosylation and revision of the structure of the trisaccharide unit. Chem. Asian J. 4, 1114-1125 (2009).

7 Ueda, J., Chijiwa, S., Takagi, M. \& Shin-ya, K. A novel versipelostatin analogue, versipelostatin F isolated from Streptomyces versipellis 4083-SVS6. J. Antibiot. 61, 752-755 (2008).

8 Zhao, P. et al. New glycosylated derivatives of versipelostatin, the GRP78/Bip molecular chaperone down-regulator, from Streptomyces versipellis 4083-SVS6. Org. Biomol. Chem. 7, 1454-1460 (2009).

9 Katsuta, R., Arai, K., Yajima, A. \& Nukada, T. Synthetic study of versipelostatin A. synthesis of the spirotetronate unit starting from pulegone. Synlett 397-400 (2012).

10 Samejima, S., Takao, K. \& Tadano, K. Synthetic studies on the upper segment of versipelostatin. The 98th symposium on organic synthesis, Japan, paper 0-3, Tokyo, 5 November (2010).
11 Sasaki, S., Ishii, M., Takao, K. \& Tadano, K. Synthetic studies on the lower segment of vesipelostatin utilizing an intramolecular Diels-Alder reaction strategy. The 10th Annual meeting of the Japanese association for the pursuit of new bioactive resources, Yokohama, 10 June (2011).

12 Matsuda, K., Nomura, K. \& Yoshii, E. Synthesis of the chiral upper fragment of tetronolide. J. Chem. Soc., Chem. Commun. 221-223 (1989).

13 Trullinger, T. K., Qi, J. \& Roush, W. R. Studies on the synthesis of quartromicins $A_{3}$ and $D_{3}$ : synthesis of the vertical and horizontal bis-spirotetronate fragments. J. Org. Chem. 71, 6915-6922 (2006).

14 Boeckman, R. K. Jr et al. Toward the development of a general chiral auxiliary, a total synthesis of $(+)$-tetronolide via a tandem ketene-trapping [4+2] cycloadditon strategy. J. Am. Chem. Soc 128, 10572-10588 (2006).

15 Zografos, A. L. \& Georgiadis, D. Synthetic strategies towards naturally occurring tetronic acids. Synthesis 3157-3188 (2009).

16 Anzai, K. et al. Synthetic studies of versipelostatin. The 102nd symposium on organic synthesis, Japan, paper 0-2, Tokyo, 8 November (2012).

17 Beszant, S., Giannini, E., Zanoni, G. \& Vidari, G. Electrophilic cyclization of 1,6-dienes containing an allylsilane moiety - Enantioselective synthesis of cis- and trans- $\gamma$-irone. Eur. J. Org. Chem 3958-3968 (2003).

18 Kozawa, l. et al. Stereoselective double alkylation of the acetoacetate ester $\alpha$-carbon on a D-glucose-derived template: application to the synthesis of enantiopure cycloalkenones bearing an asymmetric quaternary carbon. Synlett 399-402 (2007).

19 Kubo, H., Kozawa, I., Takao, K. \& Tadano, K. Stereoselective synthesis of highly enantioenriched 3-methyl-2-cyclohexen-1-ones possessing an asymmetric quaternary carbon as C4 or C-6: a sugar template approach. Tetrahedron Lett. 49, 1203-1207 (2008).

20 Akashi, Y., Takao, K. \& Tadano, K. Stereoselective $\alpha$-alkylation of methyl 6-deoxy-3,4 di-O-(tert-butyldimethylsilyl)-2-0-(2-methyl-3-oxobutanoyl)- $\alpha$-D-glucopyranoside. Tetrahedron Lett. 50, 1139-1142 (2009).

21 Munakata, R., Totani, K., Takao, K. \& Tadano, K. Highly stereoselective Lewis acid mediated conjugate radical additions to methyl $\alpha$-D-glucopyranoside derivatives tethering an unsaturated ester moiety at C-4. Synlett 979-982 (2000).

22 Totani, K., Takao, K. \& Tadano, K. Sugar as a tool for asymmetric synthesis: some effective approaches. Synlett 2066-2080 (2004).

23 Totani, K. \& Tadano, K. in Glycoscience-Chemistry and Chemical Biology 2nd edn (eds Fraser-Reid, B. O., Tatsuta, K. \& Thiem, J.) pp. 1029-1075 (Springer, Verlag, BerlinHeidelberg, 2008).

24 Totani, K., Takao, K. \& Tadano, K. Some stereoselective carbon-carbon bond-forming reactions realized by using sugar-derived chiral templates. J. Synth. Org. Chem., Jpn. 69, 1363-1374 (2011).

25 Marion, F. et al. Hydroxamates: relationships between structure and plasma stability J. Med. Chem. 52, 6790-6802 (2009).

26 Scholl, M., Ding, S., Lee, C. W. \& Grubbs, R. H. Synthesis and activity of a new generation of ruthenium-based olefin metathesis catalysts coordinated with 1,3-dimesityl-4,5-dihydroimidazol-2-ylidene ligands. Org. Lett. 1, 953-956 (1999).

27 Miyata, O. \& Schmidt, R. $\beta$ - and $\alpha$-lithiation of methyl $\beta$-methoxyacrylate: Efficient synthesis of $\alpha, \gamma$-substituted methyl tetronates-structure of aspertetronins and gregatins. Tetrahedron Lett. 23, 1793-1796 (1982). 